\title{
The Power of the Chief Justice: Choosing Panels on the Supreme Court of Canada
}

\author{
Benjamin Alarie and Andrew J. Green
}

Version Post-print/accepted manuscript

Citation Alarie, Benjamin and Green, Andrew James, The Power of the Chief

(published version) Justice: Choosing Panels on the Supreme Court of Canada (January 23, 2012). http://dx.doi.org/10.2139/ssrn.1884428

How to cite TSpace items

Always cite the published version, so the author(s) will receive recognition through services that track citation counts, e.g. Scopus. If you need to cite the page number of the author manuscript from TSpace because you cannot access the published version, then cite the TSpace version in addition to the published version using the permanent URI (handle) found on the record page.

This article was made openly accessible by $U$ of $T$ Faculty.

Please tell us how this access benefits you. Your story matters. 


\title{
The Power of the Chief Justice: Choosing Panels on the Supreme Court of Canada
}

\author{
Benjamin Alarie ${ }^{*}$ and Andrew Green ${ }^{+}$
}

January 23, 2012

\begin{abstract}
${ }^{\#}$
Unlike its US counterpart, the Supreme Court of Canada does not always sit en banc. While the Canadian Court also has nine judges, the Chief Justice has the discretion to determine whether five, seven or nine judges will hear each appeal. Perhaps more importantly, the Chief Justice can set the panel's composition. This panel-setting power can conceivably be exercised with different goals in mind. The Chief Justice may use the panel-setting power to optimize the use of the Court's scarce resources, such as by balancing workload or by assigning judges with expertise in the area of the appeal. However, this power could also be used strategically by the Chief Justice to help bring about her preferred outcomes in cases. Given that panels of five and seven judges hear approximately $70 \%$ of appeals, the strategic use of this panel selection power could have broad-reaching implications. This paper examines the panel-setting power by first discussing the reasons why the Chief Justice may not select the panel randomly. It examines efficiency based explanations as well as the implications of the Chief Justice seeking to satisfy her particular policy preferences. The paper then analyzes how Chief Justices actually used the panel-setting power using data from Supreme Court decisions during the period 1984 to 2005 .
\end{abstract}

\footnotetext{
*Associate Professor and Associate Dean, First Year Program, Faculty of Law, University of Toronto. ${ }^{+}$Associate Professor, Faculty of Law, University of Toronto.

\# The authors are grateful for comments and suggestions from Ed Iacobucci, Tonja Jacobi, Albert Yoon, and from participants at the presentation of earlier drafts of the paper at the Canadian Law and Economics Association annual meeting in October 2011 at the University of Toronto and at the Sixth Conference on Empirical Legal Studies in November 2011 at Northwestern University School of Law.
} 


\section{INTRODUCTION}

Unlike their U.S. counterparts, the nine members of the Supreme Court of Canada do not always sit en banc. The Chief Justice has the power to decide the size and composition of the panel hearing an appeal, almost always setting the panel size at five, seven or nine judges. The Chief Justice may use the panel-setting power to enhance the efficiency of the appeal process such as by tailoring the size of the panel to the nature of the case and ensuring that the workload of the Court is fairly distributed across the judges. ${ }^{1}$ It is also possible that the Chief Justice might use the panel-setting power to attempt to secure her preferred outcomes in at least a subset of appeals. This paper examines the magnitude of the potential power of the Chief Justice to alter case outcomes on the Court, and also tests the degree to which Chief Justices used this power during the period from September 1984 to June 2005.

Not all countries organize their highest court in a way that gives panel-setting powers to the Chief Justice. The nine-member US Supreme Court almost always sits en banc except where there are vacancies, illnesses or recusals. In Israel the Supreme Court sits in panels but the composition of the panels is determined randomly. Some courts that are set up similarly to the Supreme Court of Canada include the South African court and the new replacement of the House of Lords, the UK Supreme Court. The question arises whether the panel-setting power is an efficiency-enhancing tool or a lever by which the Chief Justice can sway the decisions of the court (or something else). It may, of course, depend on the disposition of the particular Chief Justice.

The potential for misuse of this panel-setting power arises because of the possibility of "attitudinal" or "strategic" decision-making by judges. As explained in Part II, there are three prominent models of how judges decide cases. They may vote in a manner that accords with legal principles and norms of statutory interpretation (the "legal" model), they may directly vote for their preferred policy outcome (the "attitudinal" model) or they may consider how their vote will interact with those of other judges or institutions in order to ensure their preferred policy position obtains (the "strategic" model). There has been considerable analysis in the literature identifying a connection between a judge's policy preferences and her voting in particular cases. ${ }^{2}$

\footnotetext{
${ }^{1}$ Benjamin Alarie, Andrew Green and Edward Iacobucci, "Is Bigger Always Better? On Optimal Panel Size, with Evidence from the Supreme Court of Canada" (May 11, 2011). U Toronto, Legal Studies Research Paper No. 08-15. Available at SSRN: http://ssrn.com/abstract=1152322.

${ }^{2}$ For the US, the literature has grown rapidly in recent years. Some important contributions include, Jeffrey A. Segal and Harold J. Spaeth, The Supreme Court and the Attitudinal Model (Cambridge University Press, 1993); Jeffrey A. Segal and Harold J. Spaeth, The Supreme Court and the Attitudinal Model Revisited (Cambridge University Press, 2002); Cass R. Sunstein, David Schkade, Lisa M. Ellman, and Andres Sawicki, Are Judges Political? An Empirical Analysis of the Federal Judiciary (Brookings Institution Press, 2006); and Andrew D. Martin, Kevin M. Quinn, Theodore W. Ruger, and Pauline T. Kim, "Competing Approaches to Predicting Supreme Court Decisionmaking" (2004) 2 Perspectives on Politics 761. In Canada, somewhat less work has been done; see, for example, Benjamin Alarie and Andrew Green, "Policy Preference Change and Appointments to the Supreme Court of Canada"
} 
If judges seek to have decisions on appeals accord with their policy preferences, the Chief Justice of the Supreme Court of Canada has a range of tools at his or her disposal to attempt to generate outcomes that the Chief Justice finds desirable. For example, she can decide which judges write particular decisions (though only if she sits on a particular panel). ${ }^{3}$ She can also seek to develop norms of consensus on the court, which may change the probability of her obtaining her desired policy outcome in a particular appeal. ${ }^{4}$ However, manipulating the composition and the size of the panels that hear the cases would be a much more direct manner in which to alter the pattern of outcomes, assuming that the Chief Justice is able to predict (at least in a probabilistic way) how judges are likely to vote in particular appeals.

The literature on how Chief Justices use their power to set panel composition is not extensive. Hausegger and Haynie examined the factors influencing panel composition from 1986 to 1997 in Canada and 1950 to 1990 (apartheid-era) South Africa. ${ }^{5}$ In order to examine whether the Chief Justices' policy preferences influenced their decisions on panel composition, they focused on the "ideological distance from the chief justice" of each judge. They calculated this variable as the absolute difference between the percent of votes in favour of the criminally accused by a judge and the percent of votes in favour of the criminally accused by the chief justice. They examine whether the Chief Justice is more likely to assign justices whose policy preferences are similar to their own to a panel, particularly a panel addressing a "salient issue," which was taken in the Canadian context to mean an appeal involving the Charter.

(2009) 47(1) Osgoode Hall Law Journal 1-46; Benjamin Alarie and Andrew Green, "Charter Decisions in the McLachlin Era: Consensus and Ideology at the Supreme Court of Canada" (2009) 47 Supreme Court Law Review 475-511 and C.L. Ostberg and Matthew E. Wetstein, Attitudinal Decision Making in the Supreme Court of Canada (University of British Columbia Press, 2007).

${ }^{3}$ In the US, studies have found that the Chief Justices tend to assign writing responsibilities to justices with similar policy preferences to their own, although some (such as Chief Justice Rehnquist) may be primarily concerned with work load issues. See, for example, Forrest Maltzman and Paul J. Wahlbeck, "May It Please the Chief? Opinion Assignments in the Rehnquist Court" (1996) American J. Political Science 421, Segal and Spaeth (Attitudinal Model Revisited) [Recent cites]. There may be other avenues for a Chief Justice to influence decisions on the Court, such as the timing of his retirement where the Chief Justice attempts to ensure he is replaced with a justice with similar policy preferences. See Tracey E. George and Albert H. Yoon, "Chief Judges: The Limits of Attitudinal Theory and Possible Paradox of Managerial Judging" [Vanderbilt L.R.]. Further, Wetstein and Ostberg found that an increase in panel size from seven to nine leads to an approximately 11 percent decrease in the likelihood of the chief justices authoring the majority opinion, concluding that "chief justices who want to advance their policy preferences might act in a strategic manner by creating smaller panels to increase their likelihood to control the writing of the majority opinion" (Matthew E Wetstein and C L Ostberg, "Strategic Leadership and Political Change on the Canadian Supreme Court: Analyzing the Transition to Chief Justice" (2005) 38:3 Canadian Journal of Political Science 653 at 664.

${ }^{4}$ For a discussion of norms of consensus and their relation to attitudinal voting, see Ben Alarie and Andrew Green, "Should They All Just Get Along? Judicial Ideology, Collegiality and Appointments to the Supreme Court of Canada" (2008) 58 UNB Law Journal 73.

${ }^{5}$ Lori Hausegger and Stacia Haynie, "Judicial Decisionmaking and the Use of Panels in the Canadian Supreme Court and the South African Appellate Division" (2003) 37(3) Law \& Society Review 635. 
Hausegger and Haynie found that the Chief Justice is actually more likely to select judges that are further ideologically from that of the Chief Justice. ${ }^{6}$ They hypothesize that the tendency of the Canadian Chief Justice to assign justices who are ideologically distant might be explained by the "chief justice's inclination to assign himself to fewer panels, preferring to participate in en banc hearings." 7 Indeed, they also found that in cases that are deemed to be more salient (civil rights and liberty issues), Chief Justices are more likely to assign judges with similar ideological views to themselves. ${ }^{8}$ They conclude that "individual chief justices are similarly motivated when considering the use of their power to assign like-minded judges to panels," although they note that their main variable indicated like-mindedness using the absolute value of the distance from the Chief Justice with the result that appointing very liberal or very conservative judges are treated equally. ${ }^{9}$

A Chief Justice may select specific combinations of judges in order to create a majority in favour of her preferred outcome. Heard examined how Chief Justices appointed panels, using Supreme Court of Canada Charter appeals between 1985 and 1989. ${ }^{10}$ He divided the judges based on their career voting records, into judges who were "more receptive" and "less receptive" to the Charter. Heard found that panels with a majority of judges who were more receptive to the Charter sat on the majority of appeals (61.5\%) in this period. ${ }^{11} \mathrm{He}$ also found that the composition of the panel was significant to the outcome of the appeal. Where the panel was predominantly receptive to the Charter, the Charter claim had a $38.5 \%$ success rate (similarly where the panel was balanced there was a $43.8 \%$ success rate). Heard found that where the majority of the panel was less receptive to the Charter, the success rate dropped by more than half to $15.9 \%$.

Similarly, Sill and Haynie examined the issue of the formation of majorities on panels, focusing on civil liberties and criminal cases before the South African SCA from 1970 to 2000.12 They examined the number of times a particular combination of justices sat together on a panel and the number of times a particular minimum winning coalition sat on a panel together. They defined a minimum winning coalition as the minimum combination of justices required for a majority opinion, which is usually two justices for criminal cases (usually a panel of three) and three justices for civil liberties cases (usually a panel of five). ${ }^{13}$ Sill and Haynie examined whether these panel combinations were related to the ideological distance for the

${ }^{6}$ Ibid at 651.

7 Ibid.

${ }^{8}$ Ibid.

${ }^{9}$ Ibid, at 653.

${ }^{10}$ Andrew D. Heard, "The Charter in the Supreme Court of Canada: The Importance of Which Judges Hear an Appeal" (1991) Canadian J. Political Science 289.

${ }^{11}$ However, they found that this percentage was reduced by the time the appeals were actually decided because of a number of illnesses.

12 Kaitlyn L Sill \& Stacia L Haynie "'Panel Assignment in Appellate Courts: Strategic Behaviour in the South African Supreme Court of Appeal" (2010) 37:1 Politikon 269.

${ }^{13}$ Ibid at 272. 
panel or minimum winning coalition, which was calculated as the absolute value of the difference between the average of the proportion of pro-criminally-accused votes each justice makes for a given panel or minimum winning coalition less the proportion of pro-criminally-accused votes of chief justice. ${ }^{14}$ They found that for the entire panel, the ideological distance of the panel has no statistical significant relationship with the repetition of panel combination. ${ }^{15}$ However, in the preapartheid era, a minimum winning combination was more likely to repeat the closer the ideological score of the majority to the chief justice. ${ }^{16}$ After 1994 , the results suggest that the chief justice is more likely to assign minimum winning coalitions that are ideologically distant. ${ }^{17}$ Sill and Haynie argued that after 1994, the chief justice had the highest recorded ideological score for the period and therefore the combinations were more likely to be further apart. ${ }^{18}$

There have also been some studies of panel assignment on the US Court of Appeals. In contrast to the Canadian, South African, and New Zealand systems, panel assignment at the United States Court of Appeal level is considered to be more, but not entirely, random. ${ }^{19}$ The United States Court of Appeal is comprised of circuits based on geographically defined areas, and each circuit is comprised of a number of justices who can be selected to serve on panels of three. Justice assignment in several circuits is now conducted by computer program, but randomization was previously manually conducted. Looking at the period of 1958 to 1966, Atkins and Zavoina analyze the distribution of panel assignments to race-based cases for the fifth circuit and found that the probability of a random distribution resulting in the number of times that three pro-rights justices were actually assigned to serve on a panel would "occur by chance one time in ten thousand." 20 Further, they found that the observed frequency of panel assignment comprising a majority of pro-rights justices was not random. ${ }^{21}$

While the US Supreme Court sits en banc, and as a result the issue of panel assignment is absent, the Chief Justice is granted appointment power for special courts. ${ }^{22}$ Looking specifically at the Burger and Rehnquist era's (both nominated by

\footnotetext{
14 Ibid at 274.

15 Ibid at 278.

16 Ibid at 280.

17 Ibid.

18 Ibid.

${ }^{19}$ J. Robert Brown, Jr \& Allison Herren Lee, "Neutral Assignment of Judges at the Court of Appeal" (1999-2000) 78 Tex L R 1037. Here, Brown \& Lee suggest that, despite claiming to be random and thus unbiased, the lack of mechanisms in place in the event of required replacements creates discretion in the judicial appointment to a panel.

20 "Burton M Atkins and William Zavoina, "Judicial Leadership on the Court of Appeals: A Probability Analysis of Panel Assignment in Race Relations Cases on the Fifth Circuit" (1974) 18:4 American Journal of Political Science 701 at 701.

${ }^{21}$ Ibid at 705. Level of significance $=0.005$.

${ }^{22}$ Ruger states that the Chief Justice has the power to: designate eleven federal district court judges to serve in seven-year terms on the Foreign Intelligence Surveillance Court, which reviews and decides government applications for electronic surveillance, and three circuit judges to sit on an
} 
Republican party Presidents), Ruger argued that this appointment power creates the ability to shape the composition of special courts to align with the views of the Chief Justice. ${ }^{23}$ Ruger found that Rehnquist appointed 74\% Republican selected justices and 26\% Democrat selected justices, and Burger appointed 46\% Republican selected justices and 54\% Democrat selected justices. However, these results are not adjusted for the Republican-Democrat distribution of the justices sitting at the time of appointment. Acknowledging this problem, Ruger draws several conclusions regarding the distribution of appointments. First, the Special Division assignment cannot be random because for twenty and a half of the twenty-two year period the composition was two-thirds Republican selected justices. Second, Burger appointed a disproportionately larger share of Republican nominated justices to the Special Division, FISA and Review Court, which address matters such as national security, civil rights, and weighing incomplete evidentiary claims in issuing a warrant. Burger also appointed a disproportionately larger share of Democrat nominated justices to Judicial Panel on Multidistrict litigation and the Temporary Court of Appeals, which address matters that Ruger calls more "specific... and relatively more neutral technical standards than other types of special courts." 24

Other studies have examined efficiency-based rationales for assigning justices to panels in Canada. Hausegger and Haynie found that length of time on the bench had an impact on panel appointments. ${ }^{25}$ First year judges on the Supreme Court of Canada were less likely to be placed on a panel than other judges. Junior judges were more likely to be placed on a panel than senior judges but less likely to be placed on a "salient" appeal.26 By contrast, for South Africa they found that senior judges were more likely to be selected to a panel than junior judges, both salient and non-salient. Similarly Ostberg et al examined whether there were "freshman effects" at the Supreme Court of Canada for the period 1973 to 1999.27 Using a difference of means test, the only statistically significant variable was the number of cases a justice participated in during their first year when compared to later years. Ostberg et al found that first year justices were assigned to 74.3 percent of cases, and by the fifth year the assignment rate jumped to 83.1 percent of cases. ${ }^{28}$ In other words, in their first year on the SCC, justices usually are assigned to fewer panels

appellate panel (50 U.S.C. § 1803(a), (b), (d) (2004)); designate five federal district court judges to serve in five-year terms on the Alien Terrorist Removal Court, which hears all alien removal proceedings (8 U.S.C. § 1532(a) (2004)); and designate five to seven district or circuit court judges to serve on the Judicial Panel on Multidistrict Litigation (28 U.S.C. § 1407(d) (2004)). Theodore Ruger, "The Judicial Appointment Power of the Chief Justice" (2004-2005) 7 U Pa J Const L 341, at footnotes 5-7.

${ }^{23}$ Ruger (2004-2005).

24 Ibid at 394.

${ }^{25}$ Hausegger and Haynie (2003). Similarly, in the US, see [cite].

${ }^{26}$ Ibid at 651-52.

27 CL Ostberg, Matthew E Wetstein, and Craig R Ducat, "Acclimation Effects on the Supreme Court of Canada: A Cross-Cultural Examination of Judicial Folklore" (2003) 84:3 Social Science Quarterly 704.

${ }^{28}$ Ibid at 712-13. 
than in later years. In addition, when analyzed individually, the results indicate that for 10 of the 15 justices, assignment rates increased after the first year. ${ }^{29}$

Who in Canada has the power to choose who wields this power to select panels? By long-standing convention, it is the Prime Minister who chooses the Chief Justice for the Court. The Prime Minister has complete discretion in appointing justices to the Supreme Court of Canada, though he tends to consult with various members of the bar, the province, and others in making the appointment. In choosing the Chief Justice when the pre-existing Chief Justice retires, Prime Ministers often choose the most senior member of the remaining justices, although this norm is not always followed. ${ }^{30}$ There is also a convention of alternating English-speaking and Frenchspeaking Chief Justices. ${ }^{31}$ The appointments process for Supreme Court of Canada judges appears to be evolving, however, with some of the more recent appointees being made subject to questioning by a Parliamentary committee. If the appointments process for other justices on the Court continues to evolve in this direction, it could conceivably also affect the appointment of the Chief Justice. ${ }^{32}$

There therefore has been limited review of how Chief Justices set panels in the literature. This paper seeks to use clearer tests for examining the extent to which Chief Justices in Canada can influence decisions through panel selection and how past Chief Justices have tended to use this power. Part II of this paper describes the possible objectives, both ideological and efficiency based, that a Chief Justice may be seeking to satisfy in establishing panels. Part III discusses our database. In this paper, we examine the period from 1984 to 2005 during which there were three Chief Justices: Chief Justice Brian Dickson (April 4, 1984 to June 30, 1990); Chief Justice Antonio Lamer (July 1, 1990 to January 6, 2000); and the current Chief Justice Beverley McLachlin (January 7, 2000 to the end of the database in June 2005). Part IV begins the discussion of the actual power of the Chief Justice by examining the extent to which a Chief Justice could change the composition of panels if that was his or her preference. We find that despite a narrower distribution of policy preferences in Canada than in the US, the Chief Justice has significant potential to shape the outcomes of appeals through panel selection. Part $V$ then turns to the actual composition of the panels struck by these Chief Justices. It first examines whether the composition was random and, finding that it was not random, asks whether these panels appear to have been set to achieve a particular policy outcome, to maximize social welfare (such as by achieving a balanced panel) or by a concern for the use of the resources of the Court such as through balancing the workload. Part VI concludes.

\footnotetext{
${ }^{29} \mathrm{Ibid}$ at 715. Note that while these results appear consistent with Hausegger and Hayine, Ostberg et al compared first year panel frequency with the same justice at a later point in time, whereas Hausegger and Hayine compared seniority by looking at different justice's panel participation at a given point in time.

${ }^{30}$ Hausegger and Haynie (2003), at 641.

31 Hausegger and Haynie (2003), at 641 [Obtain additional source]

32 See Alarie and Green (2009).
} 


\section{II "TyPES" OF CHIEF JUSTICES}

Different Chief Justices may use the power to strike panels differently. The Chief Justice may attempt to use the panel selection to efficiently deploy the resources of the Court, to set balanced panels, or to influence outcomes in a particular direction. Before discussing the competing objectives of Chief Justices and the implications for the analysis, we first need to discuss the models of judicial decision-making that underlie the assumptions in the paper. The primary model that gives rise to the concern about the power of the Chief Justice is the "attitudinal" model. It assumes that at least to some extent when judges are voting on an appeal, they vote in accordance with their policy preferences. The existing literature on the US Supreme Court generally supports the attitudinal model (that is, the assumption that judicial decision-making is based in part on policy preferences), particularly in civil rights and civil liberties cases. ${ }^{33}$ There have been fewer studies of the applicability of the attitudinal model to Canadian courts. The studies that have been done have tended to find that attitudinal factors are important to judicial decision-making but that policy preferences are (not surprisingly) not the only factor judges take into account. ${ }^{34}$

There are two other principal models of judging. ${ }^{35}$ First, the "strategic" model of judicial decisions assumes that judges do not "sincerely" or directly vote for their preferred policy outcome in each case, but instead they take into account how their votes in the particular case will affect and be affected by other actors such as other

\footnotetext{
${ }^{33}$ See, for example, Jeffrey A. Segal and Harold J. Spaeth, The Supreme Court and the Attitudinal Model (Cambridge University Press, 1993); Jeffrey A. Segal and Harold J. Spaeth, The Supreme Court and the Attitudinal Model Revisited (Cambridge University Press, 2002); Cass R. Sunstein, David Schkade, Lisa M. Ellman, and Andres Sawicki, Are Judges Political? An Empirical Analysis of the Federal Judiciary (Brookings Institution Press, 2006); and Andrew D. Martin, Kevin M. Quinn, Theodore W. Ruger, and Pauline T. Kim, "Competing Approaches to Predicting Supreme Court Decisionmaking" (2004) 2 Perspectives on Politics 761.

34 See, for example, Ben Alarie and Andrew Green, "Policy Preference Change and Appointments to the Supreme Court of Canada" (2009) 47(1) Osgoode Hall Law Journal 1-46; Ben Alarie and Andrew Green, "Charter Decisions in the McLachlin Era: Consensus and Ideology at the Supreme Court of Canada" (2009) 47 Supreme Court Law Review 475-511; C.L. Ostberg and Matthew E. Wetstein, Attitudinal Decision Making in the Supreme Court of Canada (University of British Columbia Press, 2007) ("Although a substantial amount of attitudinal decision making appears in diverse areas of law in the post-Charter Court, especially in non-unanimous cases, the impact of ideology is not as crystalclear or as systematic as that found in the US context." (at 226)); C. Neal Tate and Panu Sittiwong, "Decision-making in the Canadian Supreme Court: Extending the Personal Attributes Model Across Nations" (1989) 51 Journal of Politics 900; Donald Songer and Susan Johnson, "Attitudinal Decision Making in the Supreme Court of Canada" (Paper presented at the Midwest Political Science Association Meetings, 2002); and Thaddeus Hwong, "A Review of Quantitative Studies of Decision Making in the Supreme Court of Canada" (2004) 30 Manitoba L.J. 353.

${ }^{35}$ For a discussion of different models of judging, see Jeffrey A. Segal and Harold J. Spaeth, The Supreme Court and the Attitudinal Model Revisited, supra note 33. Chapter 2 discusses models that emphasize the effect of statute and precedent; chapter 3 introduces models of strategic considerations.
} 
justices on the court and other institutions (such as the legislature). ${ }^{36}$ Second, there is a "legal" model that assumes that judges vote in accordance with legal principles and norms of statutory interpretation and precedent. In the case of ambiguity, judges attempt to interpret the case law or statute in the manner most consistent with the aims of the statute or case law as a whole.

We do not assume that judges are unaffected by precedent and statutory language. However, our underlying methodological assumption is that judges do exercise discretion in deciding appeals, and that in doing so they inevitably draw upon and reveal information about their policy preferences and attitudes. There are two further important points to note about our approach to examining whether the Chief Justice uses his panel selection powers to attempt to bias outcomes. First, for the Chief Justice to be able to establish panels in this manner, he would have to know the policy preferences of the judges on the Court prior to them hearing the actual appeal. Even the judges themselves may not know how they will vote at that time, although Chief Justice Lamer once explained that in deciding whether to decide the appeal en banc or with a panel, he will at times canvas the judges. He stated that he engaged in this this exercise in order to ensure that a panel would not decide differently than the full court: "First, my executive legal officer helps me to flag these cases. Also, I know my colleagues and I have a fairly good idea about what they are thinking on particular issues. I might ask what the other judges think about a particular issue, even if it is not of national general importance." 37

For our purposes, what is important is that the Chief Justice has information about how the individual judges vote in general on particular issues from prior appeals. We assume that he can use this information to probabilistically predict how the other judges will decide particular cases. As discussed further in the next Part, we operationalize this by assuming that the Chief Justice uses the voting tendencies of the particular judge up to the beginning of the term in which the appeal is heard.

Second, there has been considerable work done in the US on a particular form of strategic decision-making by judges-the impact of the voting of one judge on the other judges on the panel. These "panel effects" have been found to sway judges' voting such as, for example, where a Democratic-appointed judge votes differently (more liberally) if on a panel with two other Democratic-appointed judges as

\footnotetext{
${ }^{36}$ See, for example, Lee Epstein and Jack Knight, The Choices Justices Make (Washington, DC: CQ Press, 1998) (arguing justices should be viewed as voting strategically); Thomas H. Hammond, Chris W. Bonneau and Reginald S. Sheehan, Strategic Behaviour and Policy Choice on the US Supreme Court (Stanford, CA: Stanford University Press, 2005) (presenting a formal model of strategic decisionmaking by judges); Forrest Maltzman, James F. Spriggs II and Paul J. Wahlbeck, Crafting Law on the Supreme Court: The Collegial Game (Cambridge, UK: Cambridge University Press, 2000); and Segal and Spaeth, supra note 33.

${ }^{37}$ Ian Greene, Carl Baar, Peter McCormick, George Szablowski and Martin Thomas, Final Appeal: Decision-Making in Canadian Courts of Appeal (Toronto: James Lorimer \& Company, Ltd., 1998), at 115.
} 
opposed to two Republican-appointed judges. ${ }^{38}$ While there have been a few studies that have examined voting coalitions at the Supreme Court of Canada, ${ }^{39}$ there has been little work on panel effects in Canada. For the purposes of this paper, we do not take panel effects into account. ${ }^{40}$

As a result, one of the key underlying assumptions that we are relying on for this analysis is that to at least some extent judges vote in accordance with their policy preferences and that the Chief Justice can determine these tendencies of the judges' voting record on the Court prior to the actual appeal. However, this does not necessarily lead to the conclusion that the Chief Justice will use this information to influence a panel in his preferred direction. He may disregard this information altogether or may attempt to use it to achieve some ex ante more optimal panel, such as a panel of ideologically balanced justices. We refer to the latter types of Chief Justices as efficiency-oriented while a Chief Justice who uses the information to influence the pattern of appeal outcomes we term "strategic."

\section{The Efficiency-Oriented Chief Justice}

The most benign approach a Chief Justice could take to this power to set panels is to attempt to maximize efficiency. Efficiency could be interpreted in (at least) two ways. First, the Chief Justice could take a narrow, court-resources approach to efficiency, which may be termed a "managerial" approach to panel selection. Second, she may attempt to set panels in accordance with some conception of a broader, societal interest which we term a "social welfare maximizing" approach.

\section{(i) Managerial Approach}

An important role of the Chief Justice is to ensure that the court functions smoothly. This role involves allocating the resources of the Court (the judges' time) efficiently across the universe of possible appeals. The Chief Justice may, for example, set panel size to ensure that the Court hears as many cases as is feasible. Such an aim would point toward smaller panel sizes (and in the limit all appeals being heard by panels of five judges), given that the opportunity cost of appointing a judge to an appeal is reflected in the inability of that judge to hear another appeal. ${ }^{41}$ For example, Chief Justice Lamer stated that "I will go down to five [judges] if it is an asof-right case that we would not have granted leave to, and where it appears that we

\footnotetext{
38 Sunstein et al.

39 McCormack "Birds of a Feather"

40 This may not be as problematic as it may appear to scholars familiar with the US literature. Canadian judges are considerably less likely to vote in a manner that reflects the party of the appointing Prime Minister than US judges are likely to vote in a manner consistent with the party of the nominating President; see Alarie and Green (2009).

41 For a discussion of the trade-offs involved in setting panel size from an efficiency approach, see Alarie, Green and Iacobucci (2011).
} 
are practically unanimous." 42 There is some evidence that the Chief Justice takes this opportunity cost into account in Canada. ${ }^{43}$

The managerial Chief Justice would then care about the number of appeals heard by the Court in a given year $\left(\mathrm{N}_{\mathrm{t}}\right)$. The cases can be either low effort $\left(\mathrm{n}_{\mathrm{It}}\right)$ or high effort $\left(n_{h t}\right)$. We define the low effort cases to be cases heard as of right and high effort cases as all others. Assume that the Chief Justice wants to keep the overall workload of the Court (E) constant. There are then two potentially testable hypotheses:

(a) $n_{h t}$ is inversely related to $n_{l t}$

The Chief Justice adjusts the number of hard appeals as the number of easy cases increases (taken to be exogenous in the term as they as of right). We can then see if there is an inverse relationship between the number of hard and easy cases.

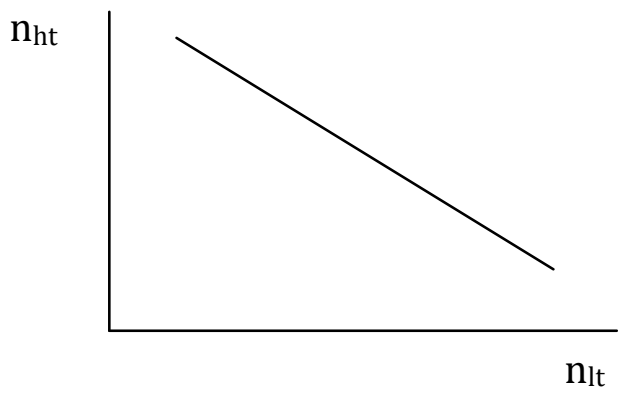

(b) The number of panels of 5 or 7 is positively related to $n_{l t}$

In order to keep the workload fairly constant in a term but also keep at or near a particular $\mathrm{N}$, the Chief Justice could reduce the number of appeals heard in panels of 9 relative to panels of 5 and 7 as the number of easy cases increases that is, the Chief Justice is not able to use the full Court as often in order to ensure the workload does not increase too much. An increase in the number of appeals heard by panels of 5 or 7 would in this scenario just be an attempt by the Chief Justice to maintain a level of effort of the Court as a whole rather than to use the selection powers to bias outcomes.

\footnotetext{
${ }^{42}$ Ian Greene, Carl Baar, Peter McCormick, George Szablowski and Martin Thomas, Final Appeal: Decision-Making in Canadian Courts of Appeal (Toronto: James Lorimer \& Company, Ltd., 1998), at 115.

${ }^{43}$ Alarie, Green and Iacobucci (2011).
} 


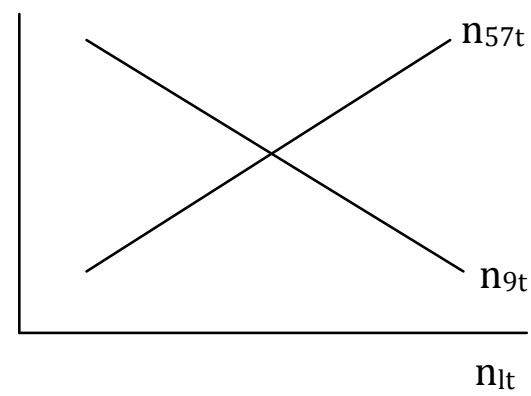

Alternatively, the Chief Justice could attempt to ensure that the workload is shared fairly - that is, he cares about $E_{i t}$ (for effort) for each judge (i) in year $t$ which depends on $\mathrm{N}_{\mathrm{t}}$. Assume first that the Chief Justice cares about the balance of the workload per judge in terms of number of appeals heard (ignoring the time spent writing for the moment). For each judge:

$\mathrm{E}_{\mathrm{it}}=\mathrm{n}_{\text {lit }}+\mathrm{n}_{\text {hit }}$

The CJ will want $E_{\text {it }}$ to be equal the Court mean workload - which would be

$\mathrm{E}_{\mathrm{it}}=\mathrm{N} / 9=\sum\left(\mathrm{n}_{\text {lit }}+\mathrm{n}_{\text {hit }}\right) / 9$

and therefore we can look for an inverse relationship between $n_{\text {lit }}$ and $n_{\text {hit }}$ - but more specifically, assuming the number of panels of 9 are fixed across the judges, we should see an inverse relationship between the number of low effort cases and the panels of 5 or 7 :

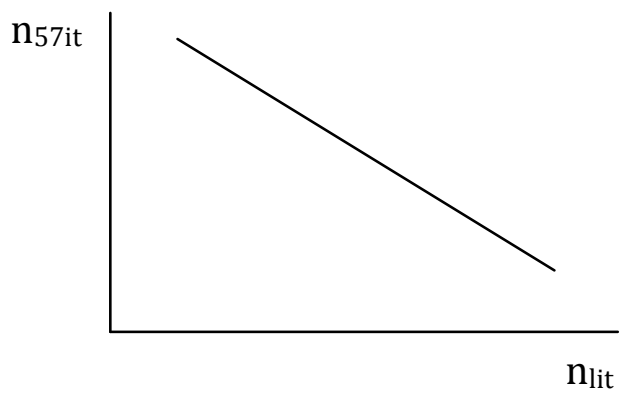

We could try controlling for some non-ideological judge specific information such as time on the Court. We may not be able to control for case type as our low effort (LTA) appeals are all based on criminal law.

Assume the CJ cares about the balance of the workload per judge including the amount individual judges are writing (w).

For each judge: 
$E_{i t}=n_{\text {hit }}+w_{\text {hit }}+n_{\text {lit }}+w_{\text {lit }}$

Again the CJ would want to make each judge essentially have a workload equal to whatever the average would be if evenly spread across all judges. We can therefore run the following regression:

$\mathrm{n}_{57 \mathrm{it}}=\mathrm{B}_{0}+\mathrm{B}_{1} \mathrm{Whit}_{\mathrm{hit}}+\mathrm{B}_{2} \mathrm{n}_{\text {lit }}+\mathrm{B}_{3} \mathrm{~W}_{\text {lit }}+\mathrm{e}_{\mathrm{it}}$

where $w_{\text {hit }}$ is the number of high effort cases for which the judge writes and $w_{\text {lit }}$ is the number of low effort cases for which the judge writes. We would expect to find negative coefficients - assuming that the CJ reduces the high workload as the writing and easy cases load increases.

When examining the actual panel selection choices, we will look to see whether the workload of the Court appears to be evenly distributed. It is of course difficult to control for the likely time and effort demands of any given appeal. The analysis will have to take into account not only the number of appeals on which a particular judge sat but also the type of case (whether it appears to be difficult or easy) and whether a judge takes on a particularly heavy load in terms of authoring judgments. If the panel assignments are not random, there may be some connection to the workload that a judge has acquired at a particular point in time in other sized panels. ${ }^{44}$

\section{(ii) Social Welfare Maximizing Approach}

The Chief Justice may, however, have a broader view of efficiency in mind when setting the size and composition of the panel. He may recognize that judges may have policy preferences or other individual characteristics that impact their vote. He may wish to set panels in order to do ensure that panels are better in some respect than would result from random assignment of judges. For example, Chief Justice Lamer stated that in setting panels he wanted to make sure that he did not set panels of less than nine if there was a risk that the panel would decide differently than the full Court. 45

The Chief Justice may also attempt to set panels to take advantage of or at least take into account the different expertise or experience of different judges. Certain judges, for example, appear to have been routinely assigned to particular types of cases. Justice Iacobucci, for example, was assigned regularly to tax appeals. ${ }^{46}$ Justice Lamer also attempted to use smaller panels based on the background of justices. He stated that all else the same he would tend to take two Quebec judges off appeals involving common law appeals (in private law) as "I would not like to see the swing vote to be

\footnotetext{
${ }^{44}$ Because our test for randomness is within panels of five and panels of seven, if there is a higher workload for some justices from panels of nine (because they are authoring a large number of opinions), this might result in them sitting on fewer panels of five or panels of seven leading to apparent non-randomness.

${ }^{45}$ Greene et al (1998), at 115.

${ }^{46}$ Cite to Alarie and Green, Reasonable Justice.
} 
in the hands of a civilian judge." 47 Similarly, he stated that "if a case is strictly on the Civil Code with no issue of general importance, I would of course include the Quebec judges, but I would not use all nine judges. I have the impression that in cases where there is a possibility of changing the common law and if a civilian judge ends up having the swing vote for the change, the judge would prefer the status quo. Now that is not a rule, but I think that it is the proper thing to do." 48

One way in which to determine whether a Chief Justice is attempting to maximize social welfare is to examine the voting records of those whom he selects to panels. In doing so, it is important to consider the information that the Chief Justice would have at the time of appointment-that is, the voting record that the Chief Justice would be aware of at a particular time. A key factor will be the voting record of the median justice. As noted above, Chief Justice Lamer stated that in setting panels, he was concerned about ensuring that the panel would decide in the same manner as the Court as a whole. This concern is one version of what it would mean to maximize social welfare. It could be based on the fact that there is a single correct answer to these questions and that is what the full Court would be able to determine and so the Chief Justice needs to ensure that that answer will result. Alternatively, it could reflect a belief that there is no objectively correct answer but that the answer depends on some form of aggregation or deliberation by the range of justices on the bench. In either event, a random result would not necessarily achieve the correct result - and therefore there is a desire to ensure a balanced panel in order to do better than random. This balance could be found by ensuring that the median justice-the swing vote-on the panel has a similar voting record to the Court as a whole. It could also be that this balance can be found by ensuring that each individual panel has justices with a range of voting records as opposed to being more heavily weighted in one direction or another.

If the $\mathrm{CJ}$ cares about something other than just workload, her utility function may be something like:

$\mathrm{U}=\mathrm{U}(\mathrm{O}, \mathrm{L}, \mathrm{A})$

where:

$0=$ the particular outcome which can be either SW for the social welfare maximizing outcome (not tied to her particular preferred policy outcome) or $\mathrm{P}$ for her preferred policy outcome (whether or not social welfare maximizing)

$\mathrm{L}=$ legitimacy of the Court (external or internal) and

${ }^{47}$ Greene et al (1998), at 116.

${ }^{48}$ Greene et al (1998), at 116. 
$\mathrm{A}=$ Afterlife (the potential return from positions the $\mathrm{CJ}$ may be able to take on after leaving the Court)

So for the Social Welfare Maximizing Chief Justice: U=U(SW, L, A)

It then depends on what the Chief Justice sees as social welfare maximizing. If she (as Chief Justice Lamer does) views it as the same outcome as a panel of nine would decide, then this outcome could feed through all three factors-that is, legitimacy (L) may depend on such panel compositions (either because the chief justice cares about $\mathrm{L}$ as a function of SW or cares about it as a function of A) as may A (if the Chief Justice wants to be viewed as fair). It is not clear which it is-but L and A may both depend directly or indirectly on whether there is some form of "balance" in panel composition.

We can then try to determine the extent to which panel decisions deviate from what a panel of nine would decide-by looking at whether the median on the panels is statistically different from the median of the Court. We would look to see if:

$\mathrm{V}_{\mathrm{mc}}-\mathrm{V}_{\mathrm{mp}}=0$

Where $\mathrm{V}_{\mathrm{mc}}$ is the voting record (liberal voting or ideal point) of the median judge on the Court at the given time and $V_{m p}$ is the voting record of the median judge on the panels. To the extent it holds, it may be because the judge is seeking to maximize SW, L or A, based on a view of balance. To extent it doesn't hold, it may be because (i) the chief justice is attempting to max own policy preferences or (ii) wants to set balance but makes mistakes. An alternate way of describing the position of the median of the panel is not as a distance from the median (that is, the size of the distance from the median) but as their rank relative to the median. The median of the full Court would be 0 with the justices arrayed from -4 to 4 on either side of the median (so the justices nearest to the median in terms of either liberal voting or ideal points would be -1 and 1 ). The test would then be whether on average the median on the panels were in the 0 position. 


\section{The Machiavellian Chief Justice}

Instead of a concern for either the allocation of court resources or a disinterested desire to find society's social welfare maximizing solution, the Chief Justice may attempt to set panel size and composition in order to achieve optimize the outcomes of the Court with respect to her preferred policy outcome. Such a tendency may be particularly evident in appeals that are important to her. If she can set a panel with the same preferences as she has or at least have the median justice have the same preferences as hers, then she may be able to increase the probability that her preferred policy outcome obtains.

If the Chief Justice is using the panel selection power to attempt to obtain her preferred outcome, the panel composition should not appear random but will instead be skewed in the direction of the Chief Justice's policy preferences. She may attempt to influence the result by choosing a panel with a particular focus on the median judge. The focus on the median justice allows us to examine how much the Chief Justice could potentially influence the voting given his choices on the bench at a given time. This examination involves determining the range of potential voting of possible median judges. It also allows us to examine whether or not he appears to have attempted to use this power to increase the probability of his preferred outcome. If, for example, the median justice on panels tends to be either in line with her preferred voting or tends have a voting record that it skewed in the direction of her preferred outcome relative to the Court median, it provides some evidence that the Chief Justice is using the power to influence outcomes. Of course, a lack of a connection between the prior voting records of justices and their placement on a panel could reflect an unwillingness to use the potential panel composition or it could mean that the Chief Justice wishes to influence panel composition in a particular direction but does not do so effectively.

\section{ThE DATABASE AND THE DiRECT AND INDIRECT ANALYSIS}

In order to analyze panel selection, we created a database that took into account the institutional features of the Court, the voting record of each justice, and the potential differences across different areas of law. The database is composed of the 2009 reported Supreme Court of Canada decisions (both appeals and references) heard from the beginning of September 1984 through to the beginning of June 2005. ${ }^{49}$ As noted above, for some of the analysis we will use one part of this period that represented a "natural court" - a period for which no justices left or joined the

\footnotetext{
49 Motions, applications and interventions were not included. This information was retrieved from the Supreme Court Reports and the LexUM website, courtesy of the University of Montreal's Faculty of Law. For more information on the manner of coding the decisions, see Alarie and Green [Appointments, Intervenors].
} 
Court.50 The "natural court" period we will use runs from January 1993 to October 1997 and had 512 decisions. We coded the cases for a number of basic categories such as outcome of appeal, ${ }^{51}$ panel size, form of contribution of each justice ${ }^{52}$ and type of party. ${ }^{53}$ In addition, we coded the cases by area of law.

Our coding is based on an approach used in recent studies of judicial attitudes in the United States and Canada. ${ }^{54}$ We coded judicial votes in the following five areas: (i) Charter appeals (where a vote in favour of the claimant is considered to be liberal, and a vote in favour of the government is considered to be conservative); (ii) criminal appeals (where a vote in favour of the defendant is considered to be liberal, and a vote in favour of the prosecution is considered to be conservative); (iii) labour appeals (where a vote in favour of a union, labour organization, or worker is considered to be liberal, and a vote in favour of an employer or business interest is considered to be conservative); (iv) tax appeals (where a vote in favour of the government is considered to be liberal, and a vote in favour of the taxpayer is considered to be conservative); and ( $\mathrm{v}$ ) aboriginal rights appeals (where a vote in favour of an aboriginal group or individual is considered to be liberal, and a vote in favour of the government is considered to be conservative). ${ }^{55}$

In order to examine the voting preferences of the justices, we used two different methods. The first method is based on a measure of the "liberal voting record" of each justice. This "direct" method examines five areas of law where votes can be more readily characterized as conservative and liberal. The votes of each individual justice in these areas are analyzed assuming these votes to be their "revealed

\footnotetext{
${ }^{50}$ Justice Major replaced Justice Stephenson in November 1992 and heard his first decision during January 1992. Justice La Forest retired and heard his last appeal in September 1997.

51 The treatment of each case was divided into three categories: appeal allowed; appeal dismissed; and mixed and appeal allowed in part. Where possible, references were sorted into one of these three categories. However those references that were only reference questions and did not fall into one of the above categories were indicated as "REFERENCE".

52 For the contribution of each justice in each decision, we examined the type of participation: concurring; majority; dissenting and dissenting in part; and unanimous. We also coded whether the justice orally delivers the judgment or writes the judgment. When no single justice has written the judgment as in a per curium decision, no single justice receives credit (there were 24 such judgments). When a justice is part of both the majority and concurring judgment, he/she is marked as a part of the concurring judgment. When a justice is part of two different concurring or dissenting judgments, he/she is marked as having a judgment of their own. Justices that dissent only in the cross-appeal are considered part of the majority.

53 This category included aboriginal group, business, government, individual, labour union, selfregulated organization and non-governmental organization.

${ }^{54}$ See, for example, Sunstein et al. supra note 33, coding as liberal any vote to grant a defendant relief in a criminal appeal (at 17 (footnote 5) and at 48), to uphold an environmental regulation or a decision in favour of a union against a challenge by industry or in favour of an individual bringing a claim of discrimination (at 19). For Canada, see for example Alarie and Green (appointments], Tate and Sittiwong; supra note 34; Songer and Johnson, supra note 34; and Ostberg and Wetstein, supra note 34 .

55 These categorizations are necessarily rough. Some finer classifications may permit more tailored results. See, for example, Staudt, Epstein, and Wiedenbeck, supra.
} 
preferences." 56 For the purposes of the analysis, we will assume that these votes reflect their underlying policy preferences. This method uses information about the different categories of the appeals to assign "liberal" or "conservative" labels to the votes of justices. ${ }^{57}$ The terms liberal and conservative may not correspond exactly to the policies typically associated with the particular types of votes. However, we are following convention in using these labels.

Our second method is based on an approach developed by Andrew Martin and Kevin Quinn, in analyzing the Supreme Court of the United States. 58 We use this alternate method (which we refer to as the indirect method) because of the potential contestability of the liberal and conservative coding of votes. The indirect method provides an ideal point distribution for each justice based on appeals on which they have sat. These ideal point distributions represent the latent policy preference predispositions of the justices-that is, they indicate which justices tend to vote in which direction. The indirect method is based on the Bayesian estimation of a one-dimensional item response theory model using a computationally intensive Markov chain Monte Carlo process. ${ }^{59}$

A number of assumptions are made in setting up the model of judicial decisionmaking that underlies the indirect method. First, it is assumed that the relevant

${ }^{56}$ Andrew Martin and Kevin Quinn, "Assessing Preference Change on the US Supreme Court" [forthcoming, Journal of Law, Economics and Organization] at 2. Available at http://jleo.oxfordjournals.org/cgi/reprint/ewm028v1

57 One of the limitations with the dataset used in this article is that it is encompasses only appeals heard and decided by the Court. In fact, most appeals require the leave of the Court in order for the appeal to be heard. Panels of Supreme Court justices decide whether or not to grant leave to appeal except for the few cases which are granted leave to appeal as of right. This process for deciding the docket of the Court provides the opportunity for a biased sample of decisions to be heard by the Court-that is, it is possible that the decision on leave to appeal could result in cases before the Court that are more or less likely to give rise to liberal or conservative votes by justices. For a discussion of this limitation on studies of the Supreme Court of Canada, see Sujit Choudhry and Claire E. Hunter, "Measuring Judicial Activism on the Supreme Court of Canada: A Comment on Newfoundland (Treasury Board) v. NAPE" (2003) 48 McGill L.J. 525 at 556. Further, there may be bias in voting records because the Chief Justice decides the size (five, seven or nine justices) and composition of the panel hearing a particular case. See, for example, Lori Hausegger and Stacie Haynie, "Judicial Decisionmaking and the Use of Panels in the Canadian Supreme Court and the South African Appellate Division" (2003) 37(3) Law \& Society Review 635 (discussing the potential bias in the selection of the composition of the panel by the Chief Justice). We cannot test for such selection issues in this article but leave these questions for future research.

58 See Andrew D. Martin and Kevin M. Quinn, "Dynamic Ideal Point Estimation via Markov Chain Monte Carlo for the U.S. Supreme Court, 1953-1999" (2002) 10 Political Analysis 134; Andrew D. Martin, Kevin M. Quinn, Theodore W. Ruger, and Pauline T. Kim, "Competing Approaches to Predicting Supreme Court Decisionmaking” (2004) 2 Perspectives on Politics 761; Andrew D. Martin, Kevin M. Quinn, and Lee Epstein, "The Median Justice on the U.S. Supreme Court" (2005) 83 North Carolina L. Rev. 1275; and Andrew D. Martin and Kevin M. Quinn, "Assessing Preference Change on the U.S. Supreme Court" (2007) 23 Journal of Law, Economics and Organization 303. Martin and Quinn maintain a website that on which they report updated empirical findings as new decisions are rendered by the U.S. Supreme Court. The website is accessible at http://mqscores.wustl.edu/.

${ }^{59}$ See Alarie and Green (2009), supra, for a more detailed discussion of the method and its implications in the Canadian context. 
attitudinal or policy space is one-dimensional-i.e., a line or spectrum. Second, the model assumes implicitly that justices vote their simple preferences, in accordance with an attitudinal model of decision-making. ${ }^{60}$ As noted above, we do not model any strategic interactions between the votes of different justices, and ignore any potential "panel effects" that may arise from certain justices being affected by the presence of other justices on the same panel. ${ }^{61}$ Thus, a vote to affirm indicates that, given their ideal policy point, affirming gives a particular justice more utility than reversing the appeal.

\section{How Much Power Does the CJ HaVe?}

One key preliminary question is, even assuming that the Chief Justice was interested in attempting to influence the outcomes of appeals, how much power would he have to do so? As noted above, studies of the US Supreme Court have found that there is a fairly discrete spread of policy preferences among the US Supreme Court justices with two distinct groups-Republican-appointed and Democrat-appointed. While the US Supreme Court does not sit in panels, if it did this wide range of preferences could potentially allow the Chief Justice to make the outcomes of appeals more predictable. Studies of the Supreme Court of Canada, on the other hand, have tended to find a more narrow distribution of policy preferences with a weaker connection to ideological markers such as the political party of the appointing Prime Minister. ${ }^{62}$ Does this narrow distribution of policy preferences on the Supreme Court of Canada leave the Chief Justice with any significant power to influence outcomes?

As can be seen in Table 1, over the terms from 1986 to 2004 the number of appeals varied significantly by term from a low of 68 in 1998 to a high of 129 in 1989 . The Court heard approximately $30 \%$ of the appeals over this period en banc, although this too varied by term from $8.5 \%$ in 1988 to $60.8 \%$ in 2002 . As a result, if the Chief Justices could influence outcomes in appeals, they could have done so in the approximately $70 \%$ of the appeals that were not heard en banc. The Chief Justices assigned approximately $25 \%$ to panels of five with Chief Justice Dickson on average setting 33\% as panels of five, Chief Justice Lamer setting 27\% and Chief Justice McLachlin setting $10 \%$ as panels of five. There were on average $45 \%$ of appeals heard by panels of seven over this period with Chief Justice Dickson setting 56\% as panels of seven, Chief Justice Lamer 43\% and Chief Justice McLachlin 40\%. These broad trends can be seen in Figure 1, below. Panels of five are in decline over the period, with most of the decline being absorbed by a corresponding increase in the

\footnotetext{
60 This assumption can be supported on the basis that given that the Martin-Quinn method uses only non-unanimous appeals, these are appeals in which justices truly do have the discretion to go either way in their disposition of the appeal.

61 This is an oversimplification. Research by Cass Sunstein in the United States has shown that panel effects can be significant on Circuit Courts of Appeal: see Sunstein et al., supra.

${ }^{62}$ Alarie and Green (2009); Ostberg and Wetstein (2007).
} 
frequency of panels of nine. The relative frequency of panels of seven appears to be relatively trendless.

Table 1: Appeals by Term ${ }^{63}$

\begin{tabular}{|c|c|c|c|c|}
\hline Term & $\begin{array}{c}\text { Total } \\
\text { Appeals }\end{array}$ & $\begin{array}{c}\text { Panels of } \\
\text { Five }\end{array}$ & $\begin{array}{c}\text { Panels of } \\
\text { Seven }\end{array}$ & $\begin{array}{c}\text { Panels of } \\
\text { Nine }\end{array}$ \\
\hline 1986 & 69 & 25 & 37 & 7 \\
\hline 1987 & 128 & 52 & 61 & 15 \\
\hline 1988 & 106 & 38 & 59 & 9 \\
\hline 1989 & 129 & 26 & 85 & 18 \\
\hline 1990 & 93 & 32 & 43 & 18 \\
\hline 1991 & 116 & 42 & 63 & 11 \\
\hline 1992 & 116 & 37 & 52 & 27 \\
\hline 1993 & 110 & 22 & 43 & 45 \\
\hline 1994 & 103 & 12 & 50 & 41 \\
\hline 1995 & 115 & 30 & 33 & 52 \\
\hline 1996 & 101 & 27 & 31 & 43 \\
\hline 1997 & 104 & 39 & 41 & 24 \\
\hline 1998 & 68 & 7 & 35 & 26 \\
\hline 1999 & 72 & 12 & 37 & 23 \\
\hline 2000 & 95 & 11 & 41 & 43 \\
\hline 2001 & 71 & 7 & 22 & 42 \\
\hline 2002 & 79 & 12 & 19 & 48 \\
\hline 2003 & 75 & 10 & 43 & 22 \\
\hline 2004 & 75 & 1 & 34 & 40 \\
\hline
\end{tabular}

As we noted in Part II, if a Chief Justice chooses to set panels of five or seven it may be an indication that he or she is following a managerial approach and not being strategic. The Chief Justice may, as noted, be using the power to set panels of less than nine to increase the number of appeals that could be heard by the Court. We stated that such a motivation would likely give rise to an inverse relationship between the number of easy cases $\left(n_{\mathrm{lt}}\right)$ and all other cases $\left(\mathrm{n}_{\mathrm{ht}}\right)$ but more importantly, a positive relationship between the number of easy cases and the number of panels of 5 or 7 (that is, the Chief Justice compensates for an increase in easy cases by increasing the numbers of appeals heard by less than the full Court). To test these propositions, we first estimated the following OLS regression:

$$
n_{h t}=B_{0}+B_{1} n_{l t}+e_{t}
$$

\footnotetext{
${ }^{63}$ Very occasionally there are panels of six or eight $(n<10)$, where judges do not sit because of illness or for other unknown reasons. These even judge panels are omitted here.
} 
For a managerial judge, we would expect that $B_{1}<0$. Further, we estimated the following OLS regressions where $n_{9 t}$ is the number of panels of 9 and $n_{57 t}$ is the number of panels of 5 or 7 :

$$
\mathrm{n}_{9 t}=\mathrm{B}_{0}+\mathrm{B}_{1} \mathrm{n}_{l t}+\mathrm{e}_{\mathrm{t}}
$$

We would expect that $B_{1}>0$. On the other hand, for panels of 5 or 7 we would expect the opposite relationship such that for the following:

$$
\mathrm{n}_{57 t}=\mathrm{B}_{0}+\mathrm{B}_{1} \mathrm{n}_{\mathrm{lt}}+\mathrm{e}_{\mathrm{t}}
$$

we would expect that in this case $\mathrm{B}_{1}<0$.

Figure 1: Proportion of Panels of Five, Seven and Nine by Term, 1986-2004

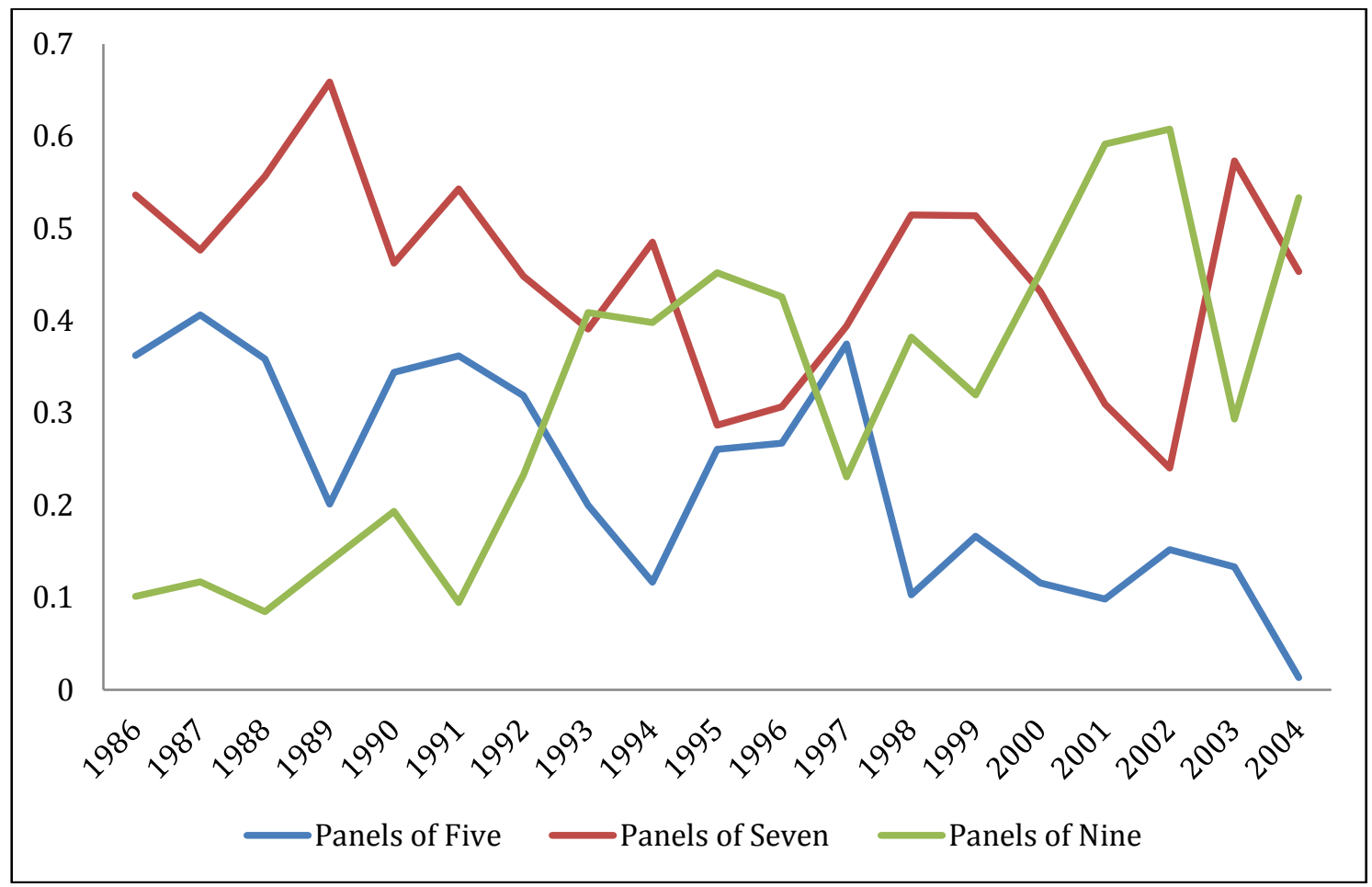

Even if there is some indication that the Chief Justices used this power to increase the number of appeals heard by the Court, it is still possible that they also used this power to increase the likelihood of particular outcomes. Using the direct and indirect method, we determined the liberal voting records and the ideal points for each justice at the beginning of each term to illustrate the scope for such a power. For a Justice's first term on the Court, we used the average of the other members of the Court, on the assumption that this would have been the best guess as to his likely voting behaviour prior to him actually hearing an appeal. We then determined 
the liberal voting record and ideal points of the median justice of the panels at either extreme (for liberal voting records for panels of five, for example, we determined the median for the most liberal panel and for the most conservative panel).

The results are shown in Figures 2 (liberal voting) and 3 (Ideal Points). Not surprisingly, there is greater room to influence the direction of an appeal in the case of a panel of five than a panel of seven, though the ranges are sometimes very tight (as in the 1992 term) and sometimes somewhat wider (as in the 2002 term). Over the entire 1986 to 2004 period, the average difference between the liberal voting percentage of the median justice of the most conservative and most liberal panels of five judges was 5.1\%, whereas for panels of seven the corresponding figure was $2.6 \%$. The ranges for the ideal points show a similar narrowing of the range for panels of seven versus panels of five. The ranges are different in part because they are examining different sets of cases. Recall that the ideal points relate to all nonunanimous decisions whereas the liberal voting record is based on all unanimous and non-unanimous cases in a given term but only for a subset of types of cases. Over the same period, the average difference between the ideal points of the median justice of the most conservative and most liberal panels of five judges was 1.21, whereas for panels of seven the corresponding figure was 0.62 .

Figure 2: Medians of Panels of Five, Seven and Nine, Liberal Voting Record

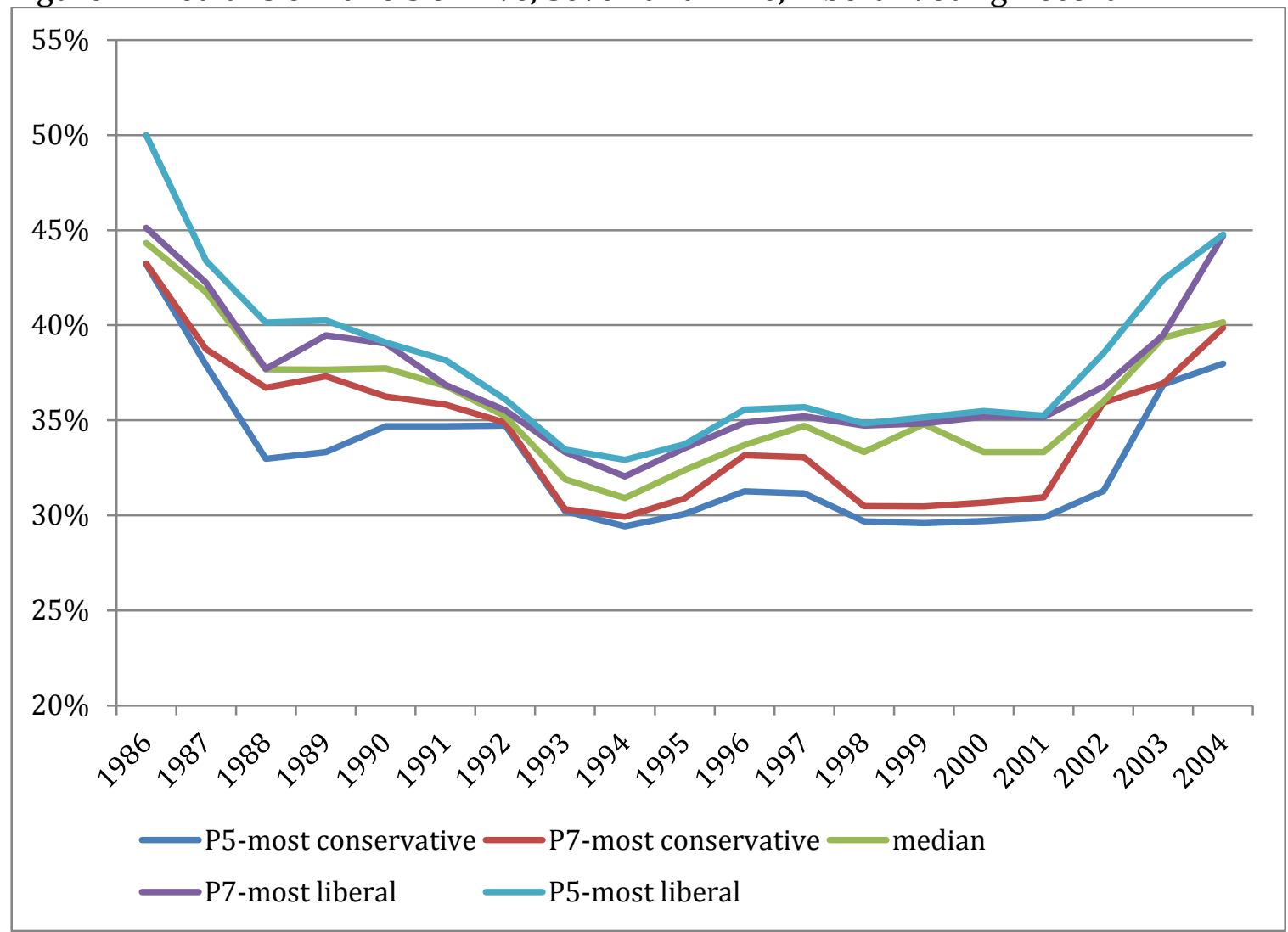


Figure 3: Medians of Panels of Five, Seven and Nine, Ideal Points

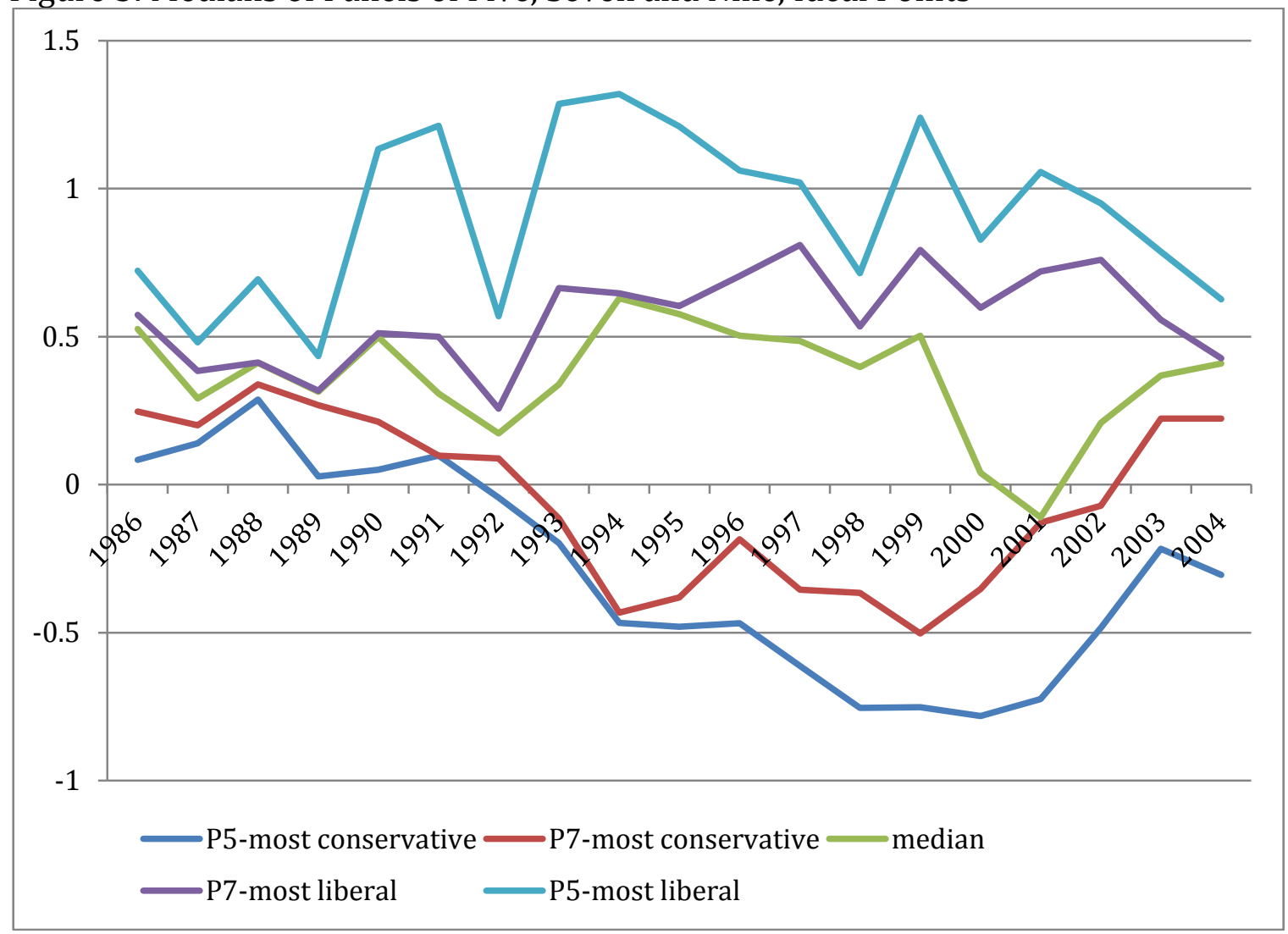

Figures 2 and 3 jointly indicate that Chief Justices did have some scope for altering the probability of a particular type of outcome given the information he had at the beginning of each term. For example, for panels of five he could have shifted the potential liberal voting probability of the median justice by as much as $7.3 \%$ (in 2002). The magnitude of the change for ideal points is more difficult to identify. However, under either measure he had the power to select from a range of median justices. Given that the Chief Justice has power to change the median justice on panels, Part V examines whether there are patterns in the way that the last three Chief Justices of the Supreme Court of Canada in fact have done so.

\section{How Were Panels Selected?}

Did the last three Chief Justices take advantage of this potential power over panel selection? In this section, we will first examine whether the panel selection appears random. As we find it does not, we then examine whether Chief Justices Dickson, Lamer and McLachlin appear to have taken a managerial approach, a social welfare maximizing approach or an approach that appears to accord more with obtaining his particular policy preferences. Do the panel selections appear to be biased in one direction or another? 


\section{Was the Panel Selection Random?}

It is possible to test the randomness of panel assignment during our sample period by using a chi-square goodness-of-fit test. It is necessary to modify the conventional form of this test in order to allow for sampling without replacement in the case of panels of five and panels of seven. Further, rather than use individual judges (which would not allow us to use the test over the whole period), we replaced each justice with his or her rank relative to the Court mean in the given term. For example, the median justice in each term was given the rank of 0 , regardless of his or her identity. The judges on either side of the median (in terms of either liberal voting or ideal points) were given ranks of -1 and 1 . In this way, we can determine whether the rate at which particular 'ranks' were assigned to panels was random.

If $m$ represents the panel size, $\mathrm{M}$ is the total number of judges on the Court, $\mathrm{D}$ is the total number of panels of particular size, $m$, that is observed, and $f_{i}$, (for judges $i=1$ through 9) is the frequency that judge i was assigned to panels of size m during the natural court period, the appropriate test statistic is given by:

$$
T=\frac{(M-1) M\left(\sum_{i=1}^{M} f_{i}^{2}-\frac{m^{2} D^{2}}{M}\right)}{(M-m) D m}
$$

Table 2 provides the results of the randomness testing. With respect to panels of seven, $m=7, M=9$ and for the full period, $D=751$, for the Dickson Court $D=182$, for the Lamer Court $D=397$ and for the McLachlin Court $D=172$. For panels of five, $m=5$, $M=9$ and for the full period $D=384$, for the Dickson Court $D=112$, for the Lamer Court $\mathrm{D}=227$ and for the McLachlin Court $\mathrm{D}=45$. As can be seen in Table 2, the test statistics using both the justices' rankings according to liberal voting rates or ideal points are in general quite high and the probabilities that the panels selections were random is essentially zero. For example, if justices are ranked by their liberal voting rates, the probability that the assignment of justices to panels of five was random was essentially zero over the whole period and during each of the Dickson, Lamer and McLachlin courts. The one exception is the assignment of justices to panels of seven by Chief Justice McLachlin for which the assignment is random at the $90 \%$ confidence level but not at the $95 \%$ confidence level. The results of the test clearly suggest that panel assignment was not random over this period. 
Table 2: Probability of Random Assignment to Panels by Policy Preference Rank

\begin{tabular}{|c|c|c|c|c|}
\hline \multicolumn{5}{|c|}{ Probability of Randomness, Panels of Seven } \\
\hline & All & Dickson & Lamer & McLachlin \\
\hline Liberal Voting & 0.000 & 0.000 & 0.000 & 0.041 \\
test statistic $\left(\chi^{2}, 8 \mathrm{df}\right)$ & 156.9 & 29.3 & 276.9 & 16.1 \\
\hline Ideal Point & 0.000 & 0.000 & 0.000 & 0.056 \\
test statistic $\left(\chi^{2}, 8 \mathrm{df}\right)$ & 200.2 & 29.9 & 260 & 15.2 \\
\hline
\end{tabular}

\begin{tabular}{|c|c|c|c|c|}
\hline \multicolumn{5}{|c|}{ Probability of Randomness, Panels of Five } \\
\hline & All & Dickson & Lamer & McLachlin \\
\hline Liberal Voting & 0.000 & 0.000 & 0.000 & 0.000 \\
test statistic $\left(\chi^{2}, 8 \mathrm{df}\right)$ & 75.9 & 66.1 & 66.7 & 49.6 \\
\hline Ideal Point & 0.000 & 0.011 & 0.000 & 0.000 \\
test statistic $\left(\chi^{2}, 8 \mathrm{df}\right)$ & 74.9 & 19.8 & 67.5 & 39.2 \\
\hline
\end{tabular}

\section{Did Lamer Take a Managerial Approach?}

If the distribution of justices across panels is not random, it does not necessarily follow that the Chief Justice is taking account of the policy preferences of each justice. It may be that the Chief Justice was attempting to balance the workload across different justices. If so, and assuming all cases are identical in terms of workload, there should be come rough equivalence in the total number of cases each justice sits on in a given year. However as can be seen by Table 3, the total number of cases per justice during the period of the natural court under Chief Justice Lamer varied widely both within each term and across the period. The Chief Justice consistently sat on a much lower number of appeals over the period, although this may in part be due to the administrative demands of the role as Chief Justice. However, even excluding the Chief Justice, there was in many terms an approximately 20 appeals difference between the heaviest load and the lightest load. Moreover over the five year period (again not including the Chief Justice whose load was considerably lighter than the other justices) the difference between the heaviest load and the lightest load was 70 appeals (Justice Sopinka sat on 459 appeals while Justice L'Heureux-Dubé on 389 appeals). 
Table 3: Appeals Heard By Justice, Natural Court Period (1992-1997)

\begin{tabular}{|c|c|c|c|c|c|c|c|}
\hline Justices & $1992 / 93$ & $1993 / 94$ & $1994 / 95$ & $1995 / 96$ & $1996 / 97$ & Total & Avg \\
\hline Lamer - Total & 54 & 75 & 61 & 67 & 65 & 322 & 64.4 \\
\hline Panels of Five & 7 & 8 & 2 & 3 & 11 & 31 & 6.2 \\
\hline $\begin{array}{l}\text { Panels of } \\
\text { Seven }\end{array}$ & 20 & 22 & 16 & 12 & 10 & 80 & 16 \\
\hline $\begin{array}{l}\text { La Forest - } \\
\text { Total }\end{array}$ & 64 & 92 & 88 & 86 & 75 & 405 & 81 \\
\hline Panels of Five & 8 & 8 & 1 & 10 & 8 & 35 & 7 \\
\hline $\begin{array}{c}\begin{array}{c}\text { Panels of } \\
\text { Seven }\end{array} \\
\end{array}$ & 29 & 39 & 44 & 24 & 23 & 159 & 31.8 \\
\hline LHD - Total & 64 & 83 & 86 & 83 & 73 & 389 & 77.8 \\
\hline Panels of Five & 9 & 10 & 3 & 7 & 9 & 38 & 7.6 \\
\hline $\begin{array}{l}\text { Panels of } \\
\text { Seven }\end{array}$ & 28 & 28 & 39 & 24 & 20 & 139 & 27.8 \\
\hline Sopinka - Total & 64 & 101 & 101 & 102 & 91 & 459 & 91.8 \\
\hline Panels of Five & 9 & 17 & 11 & 23 & 16 & 76 & 15.2 \\
\hline $\begin{array}{c}\text { Panels of } \\
\text { Seven }\end{array}$ & 28 & 39 & 46 & 27 & 31 & 171 & 34.2 \\
\hline $\begin{array}{l}\text { Gonthier - } \\
\text { Total }\end{array}$ & 64 & 88 & 100 & 102 & 85 & 439 & 87.8 \\
\hline Panels of Five & 12 & 9 & 9 & 22 & 16 & 68 & 13.6 \\
\hline $\begin{array}{c}\begin{array}{c}\text { Panels of } \\
\text { Seven }\end{array} \\
\end{array}$ & 25 & 34 & 47 & 28 & 25 & 159 & 31.8 \\
\hline Cory - Total & 65 & 92 & 97 & 102 & 90 & 446 & 89.2 \\
\hline Panels of Five & 11 & 9 & 7 & 22 & 17 & 66 & 13.2 \\
\hline $\begin{array}{c}\text { Panels of } \\
\text { Seven }\end{array}$ & 27 & 38 & 46 & 28 & 29 & 168 & 33.6 \\
\hline $\begin{array}{l}\text { McLachlin - } \\
\text { Total }\end{array}$ & 69 & 100 & 79 & 104 & 91 & 443 & 88.6 \\
\hline Panels of Five & 11 & 14 & 5 & 21 & 20 & 71 & 14.2 \\
\hline $\begin{array}{c}\begin{array}{c}\text { Panels of } \\
\text { Seven }\end{array} \\
\end{array}$ & 31 & 41 & 33 & 31 & 27 & 163 & 32.6 \\
\hline $\begin{array}{ll}\text { Iacobucci } \\
\text { Total }\end{array}$ & 70 & 99 & 97 & 99 & 88 & 453 & 90.6 \\
\hline Panels of Five & 13 & 20 & 11 & 19 & 18 & 81 & 16.2 \\
\hline $\begin{array}{c}\begin{array}{c}\text { Panels of } \\
\text { Seven }\end{array} \\
\end{array}$ & 30 & 34 & 42 & 28 & 26 & 160 & 32 \\
\hline Major - Total & 57 & 86 & 92 & 104 & 90 & 429 & 85.8 \\
\hline Panels of Five & 10 & 15 & 11 & 23 & 20 & 79 & 15.8 \\
\hline $\begin{array}{c}\begin{array}{c}\text { Panels of } \\
\text { Seven }\end{array} \\
\end{array}$ & 20 & 26 & 37 & 29 & 26 & 138 & 27.6 \\
\hline
\end{tabular}


In examining the breakdown of number of appeals by panel size, there was a consistently low representation on panels of five by three justices: Chief Justice Lamer, Justice La Forest and Justice L'Heureux-Dubé. This reduced load on panels of five does not appear to be compensated for in terms of greater work on panels of seven, particularly for the Chief Justice and Justice L'Heureux-Dubé who sat on a below average number of panels of 7 . Justice La Forest sat on an above average number of panels of 7 at the beginning of the period but was below average by the end.

In order to test whether Chief Justices balanced workload across justices, we estimated the following regression using judge specific data:

$\mathrm{n}_{57 \mathrm{it}}=\mathrm{B}_{0}+\mathrm{B}_{1} \mathrm{n}_{\text {lit }}+\mathrm{e}_{\mathrm{it}}$

As the Chief Justice may be attempting to balance out the workload by decreasing the number of hard cases a justice sits on if she takes on more easy appeals (and in fact decrease the number of panels of 5 or 7 you are, if you could assume a fixed number of panels of 9), we would expect $\mathrm{B}_{1}<0$.

A further possibility is that the Chief Justice is taking account of the amount of opinion writing a particular justice is undertaking when determining whether a particular justice will sit on a particular appeal. Again the assumption is that the Chief Justice would want to aim at each judge having a workload equal to whatever the average would be if evenly spread across all judges. We can therefore run the following regression:

$\mathrm{n}_{57 \mathrm{it}}=\mathrm{B}_{0}+\mathrm{B}_{1} \mathrm{~W}_{\text {hit }}+\mathrm{B}_{2} \mathrm{n}_{\text {lit }}+\mathrm{B}_{3} \mathrm{~W}_{\text {lit }}+\mathrm{e}_{\mathrm{it}}$

where $w_{\text {hit }}$ is the number of high effort cases for which the judge writes and $\mathrm{w}_{\text {lit }}$ is the number of low effort cases for which the judge writes. We would expect to find negative coefficients-assuming that the Chief Justice reduces the high workload as the writing and easy cases load increases.

\section{Have the Chief Justices Taken a Strategic or Welfare Maximizing Approach?}

Given that the Chief Justices do not appear to have distributed the panels randomly and that there is only limited evidence of the managerial approach, did they use the power we found in Part IV to influence the median justice on particular appeals? As there were a high percentage of the cases in each term decided by panels comprising less than the full Court, the Chief Justices potentially had the ability to make significant shifts in appeal outcomes through panel selection. In order to examine this question, we used the career voting record of the particular justices (both in terms of ideal points and liberal voting records) up until the beginning of each term. We then compared these prior career-voting records to the distribution of justices across panels. As noted above, our basic assumption was that the Chief Justice would know how each justice voted in the past and would use this knowledge to base his belief about how they would vote on a particular appeal. 
Moreover, he would update this belief periodically as each justice voted on appeals, but for our purposes only at the end of a given term. Our data for this analysis commences in September 1986. We used the terms prior to 1986 to establish the liberal voting records and ideal points of the justices on the Court at the beginning of our analysis.

In order to examine how the Chief Justices set panels, we established the rank of each justice at the beginning of term based on either their liberal voting record or ideal point scores and used these rankings to compare the panel median to the Court median. When the Court has a full complement of nine justices, the rank of the median justice is five. We then formed our dependent variable by subtracting the Court median from the rank of the justice who is the panel median. For example, suppose on a particular panel, the median justice had the third highest liberal voting score in the prior term. Her rank on the Court would be seven (as a rank of one would signify the lowest liberal voting record and nine the highest). The dependent variable (Liberal Rank) would be:

$($ Panel median rank - Court median rank $)=(7-5)=2$

Because of how we rank these justices, positive Liberal Rank values are more liberal. We formed this dependent variable using both liberal voting records and ideal points. For terms in which there were nine justices, the Liberal Rank of the median justice therefore took on five possible values $\left(-2,-1,0,1\right.$ and 2). ${ }^{64}$ In order to analyze the Chief Justices choices across these categories, we ran a series of ordered probit regressions.

\section{All Panels}

Figures 4 and 5 set out the probabilities that a particular Chief Justice will set a panel with a particular median relative to the median justice of the Court as a whole. Figure 4 provides the probabilities of a particular Liberal Rank based on the direct (liberal voting record) analysis. The ordered probit regressions for these figures use Liberal Rank as the dependent variable and controls for the identity of the Chief Justice and for whether the case was heard as of right or by leave. The probabilities shown are for each Chief Justice for decisions heard by leave.

While the figure provides the probabilities for all three Chief Justices, the probabilities for Dickson are statistically significant and the difference of McLachlin from Dickson is statistically significant at the 95\% level. However, the results for Lamer are not statistically different from Dickson. The first point to note is that

\footnotetext{
64 In some terms there were only eight justices on the Court because a justices left the Court (such as due to retirement) but was not replaced. We therefore used a Court median of 5.5 to establish a relative ranking for the Liberal Rank variable for both the liberal voting and ideal point analysis. In order to ensure that we did not skew the data, the justices' rankings from the prior term were transformed to be ranked two through nine. As a result, in undertaking our analysis we actually had nine values $(-2,-1.5,-1,-.5,0, .5,1,1.5$ and 2$)$ but we only reported the five whole number values for simplicity. The half values had very small probabilities given the low number of even panels.
} 
when all panels are considered, the probability is greater than $50 \%$ that a Chief Justice would set the panel median at the Court median. Given their power to set panels sizes and change the medians, it was more likely than not that the Chief Justices would set the panel median at the Court median either through using the full Court or setting the panel median at the Court median for smaller panels.

It is worth noting that these probabilities are not substantially greater than $50 \%$. For both Dickson and Lamer, the probability of a panel median that was one rank off of the Court median in either direction was about $17 \%$ and two off the Court median was about $2 \%$, making for a fairly balanced, normal distribution of panel medians. Chief Justice McLachlin, on the other hand, had an approximately 5\% greater probability than the other two Chief Justices of setting a panel with one rank more liberal than the Court median and $1 \%$ of setting a panel two ranks more liberal than the Court median. Correspondingly, she had a lower probability of setting panels with more conservative medians than the Court median.

Figure 4: Liberal Rank Based on Liberal Voting Record, All Panels

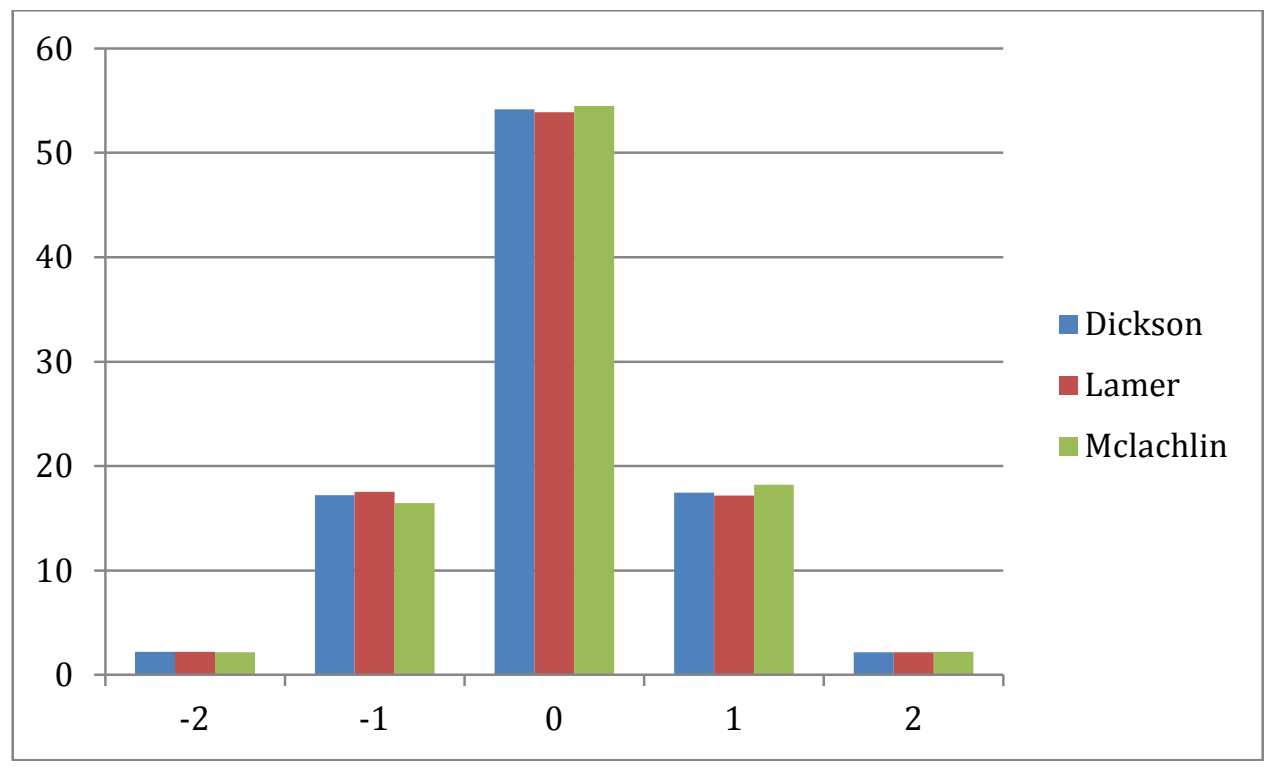

This tendency to be more likely to set panels at the Court median for all Chief Justices is also borne out by the indirect (ideal point) analysis as can be seen from Figure 4. The probability distribution for Dickson and the differences of both Lamer and McLachlin from Dickson are statistically significant at the 95\% level in this analysis. The indirect analysis, however, finds Dickson slightly more likely to set panels with more conservative medians than the Court average than either Lamer or McLachlin. Lamer continues to appear somewhat balanced between liberal and conservative medians when he does not set the panel median at the Court median. Finally, McLachlin continues to be more likely to set panels with a higher liberal median than either of the other two justices (for example, she is about $6 \%$ more likely to set a panel whose median is one rank more liberal than the Court median as 
compared to Dickson) and correspondingly less likely to set a more conservative panel median than the Court (for example, she is about 9\% less likely than Dickson to set a panel median one rank more conservatively than the Court median).

Figure 5: Liberal Rank Based on Ideal Points, All Panels

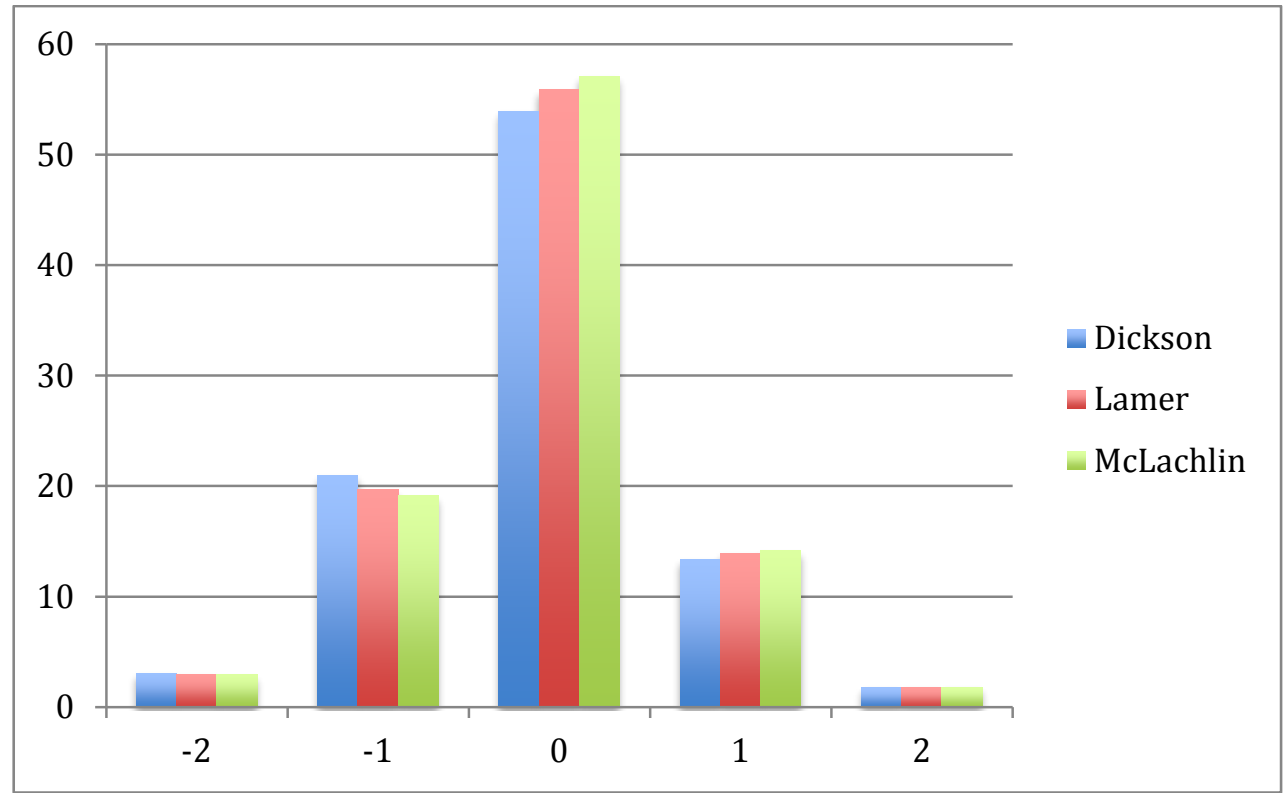

Under both the direct and indirect analysis, for all panels sitting on appeals heard with leave, the Chief Justices tended to set panels at the Court median and for panels not at the Court median Chief Justice McLachlin had a higher probability of setting a more liberal panel median than the other Chief Justices. The appeals heard with leave would tend to be the more important cases on average. One question is whether the Chief Justices tended to act any differently with appeals heard as of right, which they may view as less important and therefore be less likely to be concerned about the identity of the panel median. The coefficient on the As of Right control in the regressions were positive and statistically significant at the 95\% level indicating that the Chief Justices tended overall to set more liberal panels for appeals heard as of right than for appeals heard with leave. Examining the tendency of Chief Justices to set panels at the Court median, both Dickson and Lamer were very slightly more likely to set panels at the Court median than off the Court median for appeals as of right compared to those heard with leave. Chief Justice McLachlin, on the other hand, was very slightly less likely to set panels at the Court median for as of right appeals compared to appeals heard with leave.

\section{Panels of Five}

Examining all panels, of course, includes not only panels of five and seven but also panels of nine (that is, decision on which all justices sit). This analysis may downplay the use by a particular Chief Justice to manipulate panel selection for 
smaller panel sizes. Figures 6 and 7 set out the probabilities of the different Chief Justices setting panels that meet or differ from the Court median for appeals heard with leave. The probabilities are slightly different for liberal voting and ideal points but the main story is largely the same for Dickson. There is about a $50 \%$ probability that Dickson would choose a panel median that either equals the Court median or is one rank more liberal than the Court median (with the liberal voting analysis (Figure 6) showing a slightly higher level for a panel median a rank higher than the Court median and the ideal point analysis (Figure 7) showing a higher probability for a panel median equal to the Court median).

Figure 6: Liberal Rank Based on Liberal Voting Record, Panels of Five

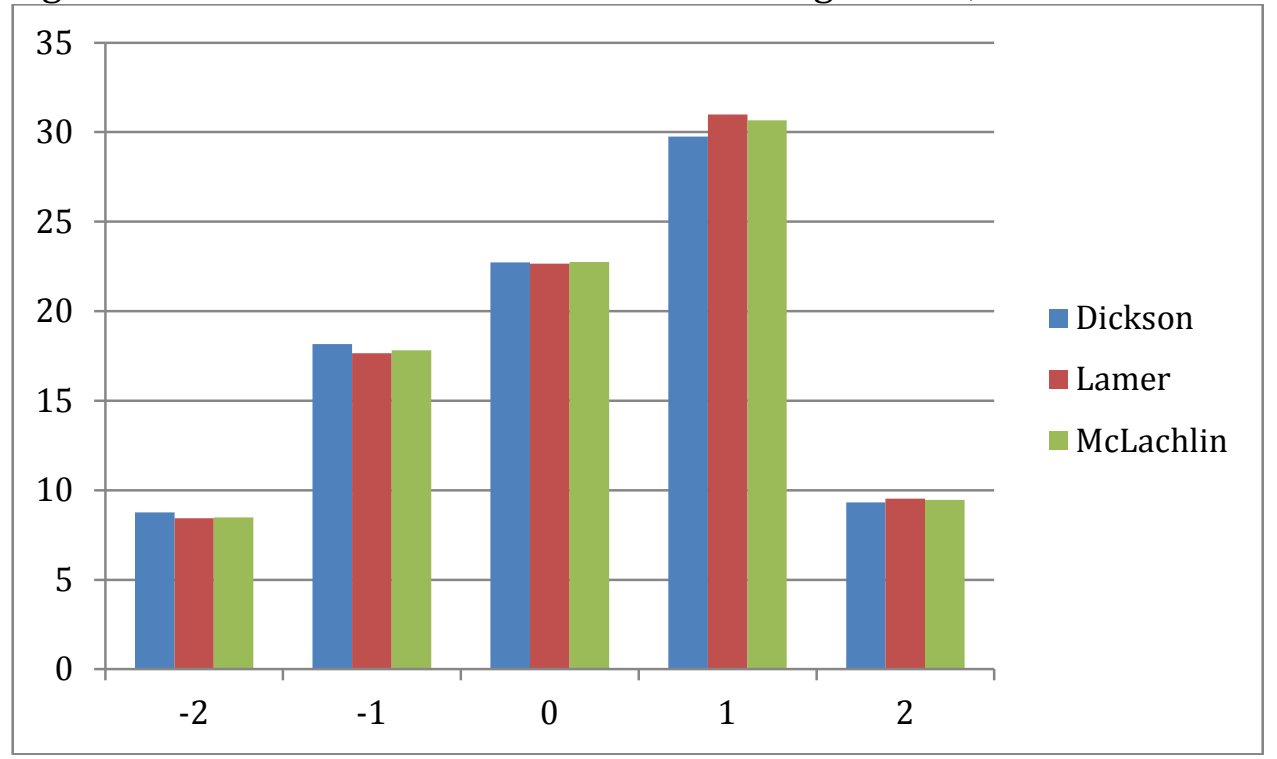

While Figure 6 provides the probabilities for Lamer and McLachlin using the liberal voting method, the difference of these probabilities from Dickson is not statistically significant. For the ideal point analysis (Figure 7), the differences between Dickson and Lamer and McLachlin are statistically significant at the 95\% level (with the exception of the difference for a -1 Liberal rank between Dickson and McLachlin which is not statistically significant). As with the analysis of all panels, above, both Lamer and McLachlin had a higher probability of setting panels with either the Court median or a median more liberal than that of the Court. Lamer in particular appears to been more likely to set a more liberal panel of five for appeals with leave. 
Figure 7: Liberal Rank Based on Ideal Points, Panels of Five

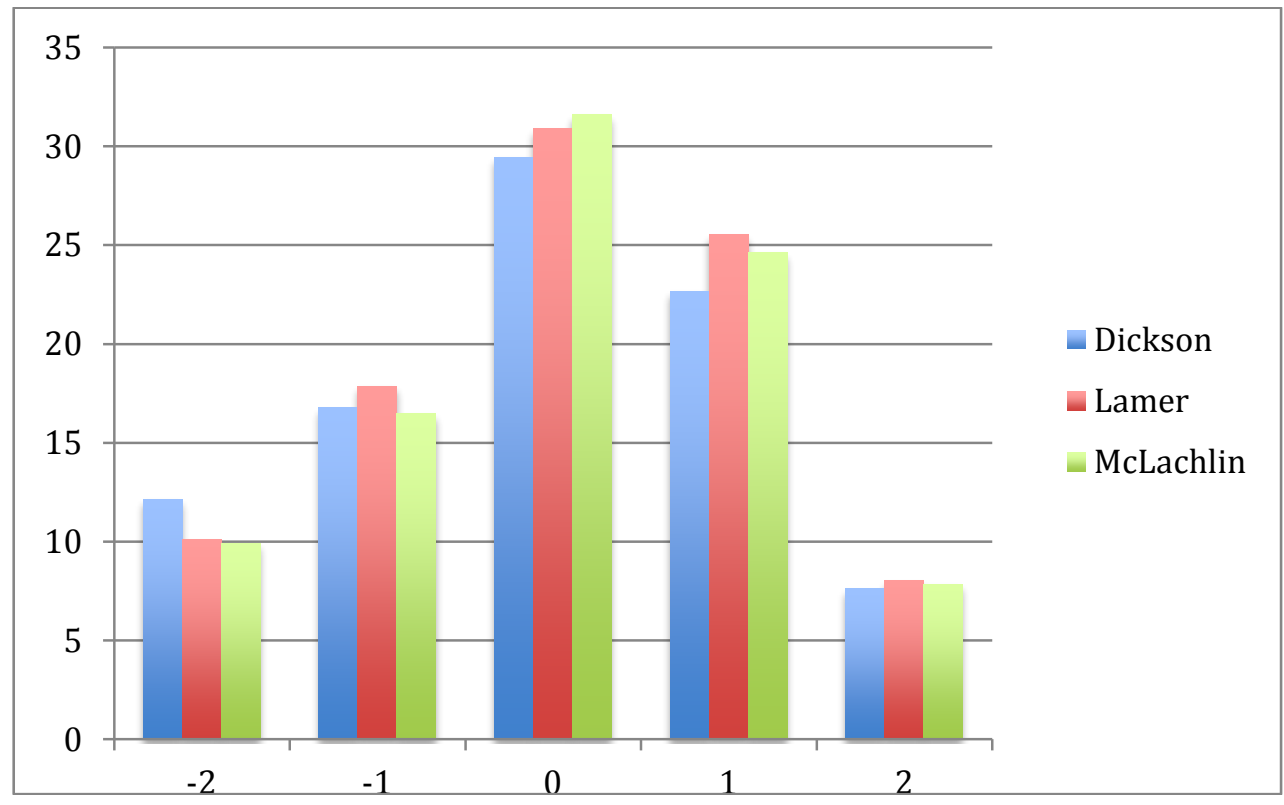

As with all panels, it is interesting to consider how the Chief Justices appoint panels of five for appeals heard as of right. Not surprisingly perhaps given they set more liberal panels for appeals heard with leave (which presumably are of greater importance than those as of right), Lamer and McLachlin tended to set the panel more conservatively for panels on appeals that are heard as of right. For both the direct and indirect analysis, the coefficient on the As of Right dummy variable is negative and statistically significant.

\section{Panels of Seven}

The Chief Justices may also be using their panel selection powers to adjust the composition of panels of seven. Figures 8 and 9 set out the results of the analysis of panels of seven for liberal voting records and ideal points, respectively, for appeals heard with leave. The Liberal Rank only includes $-1,0$ and 1 because of the larger panel size. For these panels using the direct (liberal voting) analysis, Dickson had an approximately 40 percent probability of setting a panel median at the Court median and a 29 percent probability of setting a panel median more conservatively than the Court median. Lamer was more likely than Dickson to set a conservative panel median while McLachlin was much more like to set a more liberal panel median (for example, McLachlin had an approximately 38 percent probability of setting a median more liberal than the Court median while Dickson had only a 22 percent probability). 
Figure 8: Liberal Rank Based on Liberal Voting Record, Panels of Seven

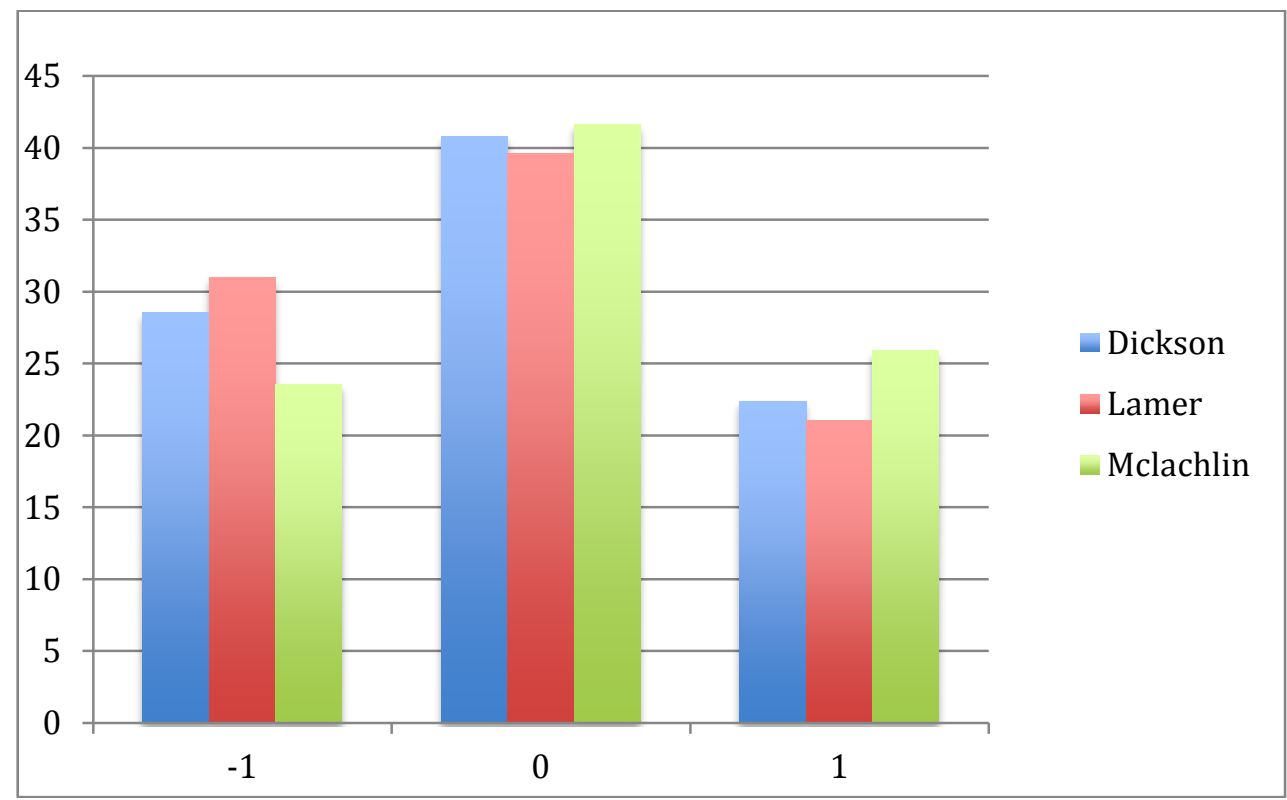

Figure 9 uses the indirect (ideal point) method and the results are very similar. Dickson has a higher probability of setting a panel with a median that is more conservative that the Court median than one that is more liberal than the Court median. Moreover, Lamer sets a slightly more conservative set of panels while McLachlin sets a much more liberal set of panel medians.

Figure 9: Liberal Rank Based on Ideal Points, Panels of Seven

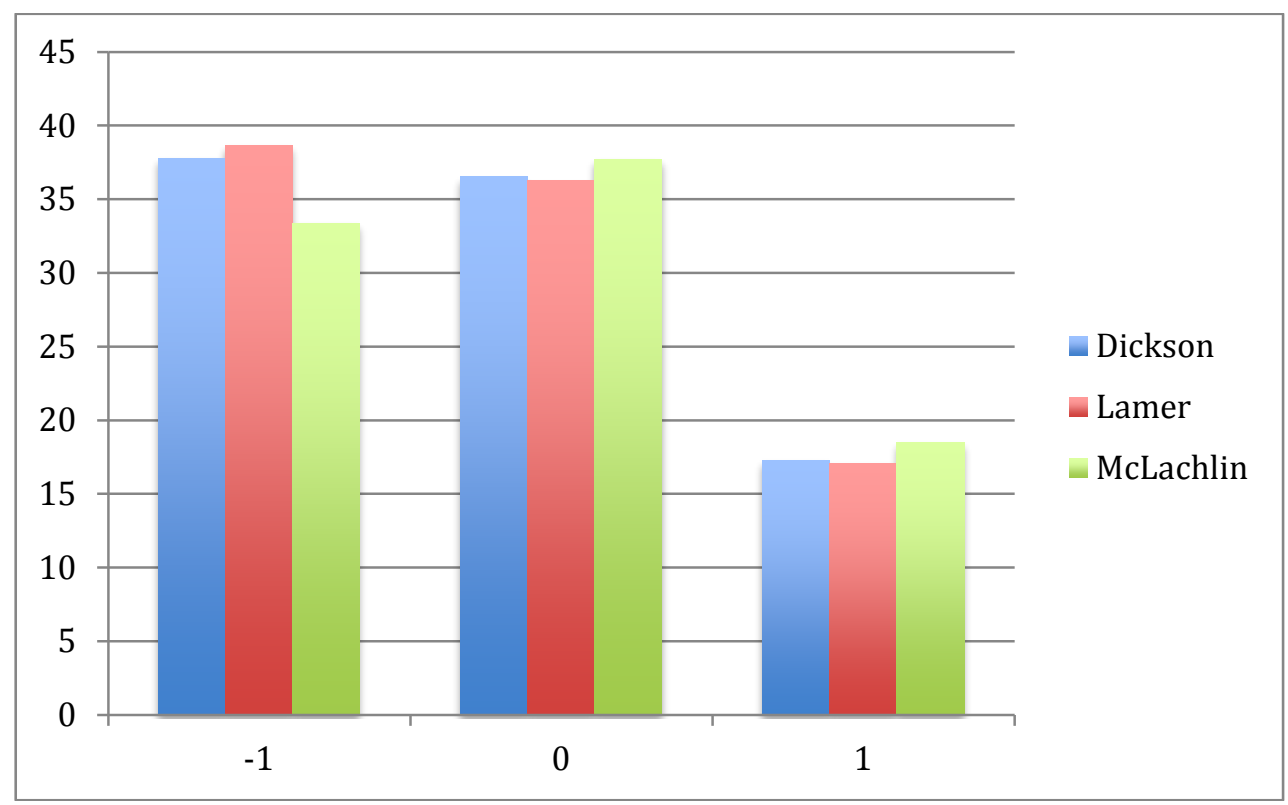


In addition, as with panels of five and all panels, the coefficient on the As of Right variable is negative and statistically significant at the $95 \%$ level. The Chief Justices therefore tended to set more conservative panels for those that were heard as of right than for those that were heard with leave.

The analysis so far has examined outcomes for all types of cases, at least in the sense that we have not separated out any particularly salient types of cases. One concern in the literature is that the Chief Justice may use the power to set panels in cases where there are particularly controversial policy issues such as human rights cases. In the Canadian context, such a concern would relate to Charter cases. ${ }^{65}$ We ran of the ordered probit regressions also controlling for area of law. We found that the basic underlying tendencies did not change when area of law in this analysis.

As a result, the examination of the medians on the panels appears to show that Chief Justices did set panels differently from each other in terms of panel medians. Dickson had a higher probability of setting slightly more conservative panels than the Court median and McLachlin had a higher probability of setting a more liberal panel. Lamer had a mixed record with a higher probability of setting more liberal panels of five and more conservative panels of seven. This tendency is apparent using both those appeals for which we assigned a liberal/conservative coding and for the ideal policy points based on all non-unanimous decisions.

\section{Does the Size of the Shift in the Median Matter?}

We also ran a second set of regression examining the relative size of the shift of the panel median relative to the Court, since this shift may not be captured by the ranking method. We ran a series of OLS regressions using the actual difference in liberal voting rates between the panel and the Court as a whole. This dependent variable (Liberal Size) therefore is found by subtracting the liberal voting rate of the justice who is the Court median from the liberal voting rate of the panel median (for example, if the justice who has the median liberal voting rate on the Court in a term has a liberal voting rate of .4 and the justice who is the median on a particular panel has a liberal voting rate of .5, then Liberal Size would take a value of .1- such that similar to the ordered probit analysis, positive numbers mean that the panel median is more liberal than the Court median).

In order to establish the panel medians for the direct method, we examined Charter, criminal and aboriginal cases as they were less controversial in their coding and there were not a large number of tax or labour cases. In determining the panel median for any given appeal, we used the cumulative liberal voting record for each justice up to but not including the particular appeal. Where there was no liberal voting record prior to the particular appeal, we used a liberal voting record of $40 \%$ as that is the mean liberal voting record over the period. For the indirect method over this period, the ideal point for a justice on a particular appeal is the ideal point for the justice for the prior term (that is, we assume the Chief Justice can identify

${ }^{65}$ See Alarie and Green (2009). 
and utilize the relative policy preference of each justice from the prior term in making panel selection choices in the current term). The only exception is that in the year a justice is appointed we used the ideal point in that year.

Table 4 reports the results of the regressions where the dependent variable is the difference between the Court median and individual panel medians. In each of the regressions, there are dummy variables for Chief Justice Lamer and Chief Justice McLachlin and the omitted justice is Chief Justice Dickson. The constant therefore reflects the extent to which Chief Justice Dickson selected panels with medians different than the Court median. The coefficients for Chief Justices Lamer and McLachlin indicate whether their selections had differences between the Court median and panel medians which were statistically significantly different than those set by Chief Justice Dickson. If the sign of the coefficient or constant is positive, it means that the Chief Justice set panels for which the panel medians were less than the Court median and if negative, the Court median is less than the panel medians. For the direct method, then, the positive (negative) sign would mean that the panels had a lower (higher) liberal voting rate (that is, were more (less) conservative than the Court as a whole). The direction of the ideal points is more difficult to conclusively connect to liberal and conservative directions, except to the extent that they tend to correspond to the directions of the direct method it provides some indication of the direction of the difference in medians. Finally, the size of the constant or coefficient in the regression using liberal voting rates reflects the actual differences in the percentage-voting rate of the panels and the Court. The sizes of the coefficients in the ideal point regressions are more difficult to assess given the uncertainty of the scale for ideal points.

Table 4: Differences in Panel Selection by Chief Justices, 1984-200566

\begin{tabular}{|l|c|c|c|c|c|c|}
\hline & \multicolumn{3}{|c|}{ Liberal Voting } & \multicolumn{3}{c|}{ Ideal Points } \\
\hline Variable & $\mathbf{1}$ & $\mathbf{2}$ & $\mathbf{3}$ & $\mathbf{4}$ & $\mathbf{5}$ & $\mathbf{6}$ \\
\hline Constant & $.002^{* *}$ & $.002^{* *}$ & .001 & $.035^{* *}$ & $.061^{* *}$ & -.008 \\
& $(.0006)$ & $(.0006)$ & $(.0008)$ & $(.0119)$ & $(.0123)$ & $(.0177)$ \\
\hline CJ Lamer & .001 & $.001^{*}$ & $.002^{* *}$ & $.070^{* *}$ & $.079^{* *}$ & $.0956^{* *}$ \\
& $(.0007)$ & $(.0007)$ & $(.0007)$ & $(.0152)$ & $(.0151)$ & $(.0153)$ \\
\hline CJ McLachlin & $-.004^{* *}$ & $-.004^{* *}$ & $-.003^{* *}$ & $-.118^{* *}$ & $-.124^{* *}$ & $-.099^{* *}$ \\
& $(.0009)$ & $(.0009)$ & $(.0009)$ & $(.0185)$ & $(.0183)$ & $(.0190)$ \\
\hline As of Right & & $-.002^{* *}$ & $-.003^{* *}$ & & $-.106^{* *}$ & $-.093^{* *}$ \\
& & $(.0007)$ & $(.0007)$ & & $(.0147)$ & $(.0155)$ \\
\hline Panel of 5 & & & $.003^{* *}$ & & & .015 \\
& & & $(.0009)$ & & & $(.0194)$ \\
\hline Panel of 7 & & & $.002^{* *}$ & & & $.102^{* *}$ \\
& & & $(.0008)$ & & & $(.0158)$ \\
\hline R-Squared & 0.016 & 0.021 & 0.027 & 0.057 & 0.081 & 0.104 \\
\hline
\end{tabular}

66 Note: The dependent variable is the difference between the Court median for the term and the median on individual panels. All regressions have 2009 observations. The values in parentheses are the standard errors. ${ }^{* *}$ indicates significance at $95 \%$ level. ${ }^{*}$ indicates significance at the $90 \%$ level. 
Turning to the regression results in Table 4, regressions 1 and 4 involved regressing the difference in medians on the dummies for Chief Justices Lamer and McLachlin using the direct (liberal voting) method and the indirect (ideal point) methods, respectively. The constants are both positive and significant indicating that Chief Justice Dickson tended to set panels which were more conservative than the Court median. Further, for both regressions the coefficient for Chief Justice McLachlin was negative, significant and larger than the constant. These results point to Chief Justice McLachlin setting panels that were statistically different than those of Chief Justice Dickson and (at least from regression 1) more liberal than both Chief Justice Dickson and the Court. The coefficients for Chief Justice Lamer are both positive indicating that he set even more conservative panels than Chief Justice Dickson but only the indirect method yielded a statistically difference between their choices.

These results show that there are differences across Chief Justices and that the panels were not set identically to the Court median. However, the size of the difference also matters. Regression 1 indicates that the medians of panels set by Chief Justice Dickson had on average a liberal voting record that was approximately 0.2 percent lower than the Court median. Further, the difference between the choices of Chief Justice Dickson and Chief Justice McLachlin was approximately 0.4 percent and between Chief Justices Dickson and Lamer was statistically insignificant. In other words, there may be in some cases a statistical difference in the medians of the panels set but the impact was extremely small.

The size and direction of impact remains the same in regressions 3 and 5 which control for whether the case was heard as of right or by leave in the direct and indirect method, respectively (although the difference between Chief Justices Dickson and Lamer now becomes significant at a 90 percent level). The sign on the as of right dummy variable is negative in each case indicating that the Chief Justices were likely to assign panels with a more liberal median than the Court to as of right cases, although again the size of the difference is very small. ${ }^{67}$

Finally, regressions 3 and 6 further control for panel size, with panels of nine being the omitted category. The constant in both cases is no longer statistically significant-that is, Chief Justice Dickson did not set panels with medians significantly different than the Court median once panel size is taken into account (which makes sense given that it is capturing panels of nine). The coefficients for Chief Justices Lamer and McLachlin are statistically significant and of the same sign and general size as in the previous regressions (that is, small). The coefficients on the panels of five and seven indicate that the Chief Justices tended to set more liberal panels for smaller panels (although the coefficient for panels of five using the indirect method is not statistically significant).

These regressions indicate that there were differences in how the Chief Justices set panels. They tended to set panels that were different than the Court median and

${ }^{67} \mathrm{We}$ also ran these regressions controlling for case type and the results were similar. 
different from each other. However, the size of the difference at least using the direct method was exceedingly small. If the Chief Justices were using the panels to further their ideological preferences they did not do so to a large extent.

\section{Panel Selection on the Supreme Court}

The Chief Justice of the Supreme Court of Canada has been given significant power to affect the outcomes of appeals through the selection of the size and composition of the panels hearing appeals. It would seem surprising, particularly for US observers, that she would not use this power to foster outcomes in line with her preferred policy positions. Our analysis of the use of this power by the last three Chief Justices indicates that the panel assignment was not random and there are statistically significant differences in how each Chief Justice used the power.

In light of this non-randomness, the question is how best to describe the approaches of the Canadian Chief Justices. Did the Chief Justices adopt a managerial, socialwelfare maximizing or strategic approach in setting panels? And if there is not a clean answer, what mixes of influences appear to give the best account of the statistical evidence?

The large variance in the number of cases heard by each justice over this period seems to point away from a managerial approach based on leveling the workload across justices of the Court. This conclusion is somewhat tempered when the number of opinions authored by different justices is taken into account. The Chief Justices may be basing panel assignment in part on the extent to which a justice has taken on a heavier writing load. This possibility is strengthened by the recognition that some judgments may be more onerous to craft than others, something that our analysis does not explicitly encompass.

In examining the policy preferences of the median justices on panels, there is some evidence that the Chief Justices were at times social welfare maximizing (or at least seeking to ensure intra-Court neutrality) in the sense that it appears that they attempted to set panels whose median or swing voter would match that of the entire Court. ${ }^{68}$ In the majority of appeals the panel median was set at the Court median for each Chief Justice. However, when the panel selections are broken down by panel size, it is apparent that the Chief Justices made different choices as to the panel median. Chief Justice Dickson was more likely to set more conservative panels than Chief Justice McLachlin who was most likely to set more liberal panels. Chief Justice Lamer had a mixed record with more liberal decisions for panels of five and more conservative for panels of seven. Also, in line with the notion that panels for appeals as of right and appeals heard with leave may be set differently given their different importance, Chief Justices Lamer and McLachlin tended to set more conservative panels for appeals as of right.

${ }^{68}$ This assumes, of course, that the composition of the Court is set in a social welfare maximizing way, which is of course likely to be contentious. 
While this analysis does not point towards extensive use of the power to set panels to influence the outcomes of particular appeals, more work is needed. It would be useful to use further tests of the link between panel assignment and other case specific factors (such as the political importance of an appeal), judge specific factors and judge combinations (such as which judge combinations re-occur).

In light of our analysis, therefore, it appears that the Chief Justices of the Supreme Court of Canada from 1984 to 2005 did not exert their power to set panels to its maximum in terms of ideology. Part of the explanation of this unwillingness to use this power ideologically may stem from the appointment process for justices of the Supreme Court which has, at least in the past, tended to foster a less political selection than in the United States. ${ }^{69}$

As we have discussed in our earlier work, ${ }^{70}$ there is reason to be concerned that with an evolution toward a more politicized selection process for the judges of the Supreme Court of Canada, the power of the Chief Justice to set panel size and composition will become both much more powerful and be deployed with less care by Chief Justices. The sorts of tests that we have conducted will potentially be important "canaries in the coal mine" to assess the politicization of the Court in the future. Stay tuned.

${ }^{69}$ Alarie and Green (2009).

${ }^{70}$ Ibid. 